Original Research

\title{
Pozzolanic and Cementing Activity of Raw and Pyro-Processed Saudi Arabian Red Mud (RM) Waste
}

\author{
Omar Alelweet, Sara Pavia *, Zehao Lei
}

Dept of Civil engineering, University of Dublin, Trinity College Dublin, Ireland; E-Mails: alelweeo@tcd.ie; pavias@tcd.ie; zlei@tcd.ie

* Correspondence: Sara Pavia; E-Mail: pavias@tcd.ie

Academic Editor: Paulina Faria

Special Issue: Wastes, Residues and Byproducts for the Production of Construction Materials

Recent Progress in Materials

2021, volume 3, issue 4

doi:10.21926/rpm. 2104047
Received: September 28, 2021

Accepted: November 11, 2021

Published: November 29, 2021

\begin{abstract}
This paper investigates the composition, properties and reactivity of a red mud waste generated in Saudi Arabia with a view to find alternative materials to replace construction binders of high environmental impact. The phase transformation triggered by the sintering of the RM up to $1000^{\circ} \mathrm{C}$ is determined with thermal and X-Ray Diffraction analyses. Reactivity is investigated with chemical and physical methods including the Chapelle test, setting times, mechanical index and microscopy. The RM is clearly pozzolanic, and its activity is mainly due to the reaction of feldespathoids and the formation of zeolitic and feldspathoid-based hydrates. The positive effects of the thermal treatment are seen below $750^{\circ} \mathrm{C}$, and include the loss of water in the zeolite/feldespathoids, and the destruction of the crystal structures of the clay minerals inherited form the parent bauxite. The negative effects of the thermal treatment are evidenced over $750^{\circ} \mathrm{C}$, with a decrease in specific surface area, devitrification and crystal formation, whereby the active transition aluminas and the fedespathoids/zeolites (mainly cancrinite) transform into nepheline, tricalcium aluminate $\left(C_{3} A\right)$ and gehlenite. Despite the occurrence of nepheline, $\mathrm{C}_{3} \mathrm{~A}$ and gehlenite in the $\mathrm{RM}$ sintered at $1000^{\circ} \mathrm{C}$, the formation of pozzolanic hydrates that cause setting and strength development are greater at lower temperature. The optimum thermal treatment that enhances pozzolanic activity lies at
\end{abstract}


c. $400^{\circ} \mathrm{C}$, as evidenced by the highest lime combination, the greatest mechanical index and the fastest set. The RM consists of gibbsite and boehmite, inherited from the bauxite, and cancrinite, chantalite and sodalite formed during the Bayer process. Feldespathoids have formed, instead of zeolites, due to the available silica and the high alkali content of the RM. The quick lime - $\mathrm{CaO}-$, added twice during the refining process, has transformed the original goethite into hematite, and produced cancrinite. The Saudi RM has high $\mathrm{SiO}_{2}$ and high alkalinity, and an abundant specific surface area available for reaction. The chloride and carbon contents are low, and no environmental toxicity is inferred from its chemistry.

\section{Keywords}

Red mud; pozzolanic activity; thermal activation; zeolites; feldspathoids

\section{Introduction}

Red mud ( $R M)$ waste is produced in large volumes when refining bauxite for the production of aluminium. Between 1 and 1.5 tons of RM waste are generated to obtain 1 ton of aluminum oxide [1]. Annually, 150 million tons of red mud are produced [1-3] and it is estimated that 30 billion metric tons are already accumulated worldwide [4].

The high alkalinity of the RM can pollute water, land and air, and high costs are associated with the large areas required for the storage of the residue. The management of this residue can pose a complex environmental impact and requires the development of technological solutions that use the residue at large scale. The disposal of RM represents a significant proportion of the overall alumina production cost, and it has been a concern for alumina refiners worldwide for years [5]. The Ma'aden Mining Industries of the Kingdom of Saudi Arabia are one of the main world producers. They generate circa 6,000 tonnes of RM per day (over $2 \mathrm{Mtpa}$ ) which results in disposal problems and high land decommissioning costs for landfill disposal. This paper intends to establish the potential of this RM waste for sustainable binder production.

Due to its composition, RM can be used in the cement and ceramic industries. When fired, it becomes a viable ceramic material which can be used to manufacture tiles, bricks and insulating materials [5]. The use of RM in Portland cement (PC) production has attracted the attention of researchers since the 1970s. Pontikes and Angelopoulos [6] reviewed existing literature where various authors used RM (as a source of Fe and Al oxide) in cement manufacturing, concluding that the majority of iron and alumina-rich phases in the RM, participate in the production of hydraulic phases $\mathrm{C}_{3} \mathrm{~A}$ and $\mathrm{C}_{4} \mathrm{AF}$; and that the addition of 2-10 wt.\% of RM improved the burnability of the clinker, reducing the temperature at which melt formation occurred by $200{ }^{\circ} \mathrm{C}$. RM was also used in calcium sulfoaluminate cement production [6]. However, the alkalinity of RM limits its application as PC clinker replacement. RM has also been used to neutralise acidic soils, as a treatment for iron deficient soils and to remove toxic heavy metals from solutions [5].

The recovery of alumina and soda, iron, titanium dioxide and other minor elements such as vanadium and rare earths from bauxite residues has been attempted without commercial success [5]. In Ma'aden, to recover alumina and soda from RM through sintering and hydrothermal routes involve billion-dollar capital costs, hence these are not realistic options. According to the Ma'aden 
Mining Industries, an economically viable disposal option has not yet been found, and at least 5$10 \%$ RM recycling needs to be achieved to make a disposal option economically viable. To date, due to its high alkalinity, only small quantities RM (3 wt.\%) have been incorporated into PC. The pozzolanic activity of the Saudi RM has not yet been studied. This paper explores the properties, composition and reactivity of the Saudi RM with a view to replace traditional non-sustainable binders in construction.

The composition of the RM residue depends on the composition of the parent bauxite and the conditions of the alumina refining (Bayer) process.

Bauxite is mainly a mixture of hydrated aluminium oxides and iron phases. The Bayer process involves the digestion of crushed bauxite in a concentrated, caustic, sodium hydroxide solution at temperatures up to $270^{\circ} \mathrm{C}$. Under these conditions, the majority of the aluminium containing species in the bauxite - such as gibbsite and boehmite- dissolve, leaving an insoluble residue (RM) composed of iron oxides, quartz, sodium aluminosilicates, calcium carbonate/ aluminate and, generally traces of titanium dioxide [5]. According to previous authors [5, 7, 8] during the refining process, silica can dissolve to form silicate as follows:

$$
2 \mathrm{NaOH}+\mathrm{SiO}_{2} \rightarrow \mathrm{Na}_{2} \mathrm{SiO}_{3}+\mathrm{H}_{2} \mathrm{O}
$$

RM typically includes sodalite, cancrinite, dawsonite and calcium-containing phases resulting from the Bayer process, and gibbsite $\left(\mathrm{Al}(\mathrm{OH})_{3}\right)$ and boehmite $(\gamma$-AlOOH) as undigested material inherited from the bauxite [8]. The organic compounds present in $\mathrm{RM}$ can form sodium oxalate- $\mathrm{Na}_{2} \mathrm{C}_{2} \mathrm{O}_{4}$ - in the alkaline $(\mathrm{pH}=14)$, high ionic strength (6-7 $\left.\mathrm{M}\left[\mathrm{Na}^{+}\right]\right)$liquors typical of the Bayer process [5].

RM waste from different bauxite refineries in the world has been compared indiscriminately by previous authors. However, some of these RM residues are distinctively cementitious, they differ widely from their pozzolanic counterparts and should not be directly compared. This is the case of the Chinese Shandong Aluminium Plant, where the RM waste includes highly reactive minerals, $C_{3} A$ and $\mathrm{C}_{2} \mathrm{~S}$, hence having significant hydraulic properties. The Chinese process of sintering alumina is different from the Bayer process which is applied in most bauxite refining plants. Here, due to the low $\mathrm{Al}_{2} \mathrm{O}_{3} / \mathrm{SiO}_{2}$ of the Chinese bauxite ore (average 5-6), the bauxite is calcined at $1200^{\circ} \mathrm{C}$ before extracting the alumina with caustic soda, and reactive hydraulic phases $C_{3} A$ and $C_{2} S$ form as a result of the high temperature of the refining process. The presence of 50 and $56 w t . \% \beta-C_{2} S$ has been reported due to the special processing of this Chinese bauxite [9]. As it is well known in cement technology, $\beta-C_{2} S$ is the most hydraulic belite polymorph. Liu et al [10], also found a strong cementitious activity in the Shandong RM: Besides the high amount of $\mathrm{C}_{2} \mathrm{~S}$ initially present, additional poorly-crystallised $\mathrm{C}_{2} \mathrm{~S}$ is formed with the $\mathrm{CaO}$ derived from the decomposition of aragonite $\left(500-600^{\circ} \mathrm{C}\right)$ and $\mathrm{SiO}_{2}$ derived from the decomposition of amorphous aluminosilicates, a metastable phase that transforms into highly crystallised, less active, $\mathrm{Ca}_{2} \mathrm{SiO}_{4}$ by increasing the temperature from $700^{\circ} \mathrm{C}$ to $900^{\circ} \mathrm{C}$. Similarly, Yalcin and Sevinc [11] report the formation of sodium ferrite $\left(\mathrm{NaFeO}_{2}\right)$ in Turkish red mud at $500^{\circ} \mathrm{C}$.

However, most of the RM residues worldwide are pozzolanic. Previous authors attempted to increase pozzolanic activity through heat treatment, but the results disagree, probably because the composition of the parent bauxite and the conditions of the Bayer process differ in alumina plants over the world. Pera et al [12] found that RMs calcined at $600-800^{\circ} \mathrm{C}$ were pozzolanic but their activity was low, and the reaction started at 3 days. They claim that the aluminium hydroxides 
(boehmite and gibbsite) develop pozzolanic behaviour when calcined between 600 and $800^{\circ} \mathrm{C}$, and that RM reactivity increases over $700^{\circ} \mathrm{C}$. Manfroi et al [13] account that RM calcined at $600^{\circ} \mathrm{C}$ has high pozzolanic activity, while Shi et al [14] obtained eminent pozzolanic activity by heating a RM of high kaolinite content at $750^{\circ} \mathrm{C}$. However, RM can be inert up to $900^{\circ} \mathrm{C}$. According to Sglavo et al [15], up to $900^{\circ} \mathrm{C}$, the main components $\left(\mathrm{Fe}_{2} \mathrm{O}_{3}\right.$ and $\mathrm{TiO}_{2}$ - which account for $50 \%$ of the original mass) maintain their original state, and nepheline and $\mathrm{Na}_{2} \mathrm{Si}_{2} \mathrm{O}_{5}$ form in the $900-1100^{\circ} \mathrm{C}$ interval.

This paper studies the pozzolanic and cementing activity of raw and sintered, Saudi RM. It explores the evolution of crystalline phases and their reactivity with increasing temperature. Reactivity indicates how quickly a pozzolanic material would combine lime (calcium hydroxide) to form cementing hydrates that provoke setting and eventually hardening. Measuring reactivity is complex and dependent on the methodology. In this research, reactivity was determined with chemical and physical methods. These include setting times, the Chapelle method, and strength development of standard mortars and pastes. The mechanical index (which measures reactivity by monitoring the compressive strength development of lime: RM mixes in relation to a standard lime mix) was also calculated and compared with other pozzolanic materials.

\section{Materials and Methods}

RM waste and the parent bauxite, from the Ma'aden Mining Industries, were studied. The RM was studied both raw and sintered at several temperatures to enhance reactivity. As aforementioned, the composition of the RM depends on conditions of the Bayer process such as the addition of lime and the washing efficiency. Lime addition is determined by the type of bauxite ore. The washing efficiency dictates the amount of soluble soda remaining in the RM and hence its alkalinity. In Ma'adem, temperatures between 260 and $270{ }^{\circ} \mathrm{C}$ are used, and quick lime -CaO - is added twice during the process. The lime transforms the iron compounds from goethite (which interferes with the separation of Al) into hematite, and helps transform the unstable Al oxides in solution, in the high-temperature digestion units, into stable phases. Lime is also added in the clarification stage, to separate the solid phase (RM) from the liquid phase [16].

\subsection{Chemical, Mineral Composition and Physical Properties of the RM}

The chemical composition was determined by XRF elemental quantitative analysis, with a ThermoFisher Scientific and Edwards Analytical using a Quant'X EDX Spectrometer and UniQuant analysis package. The results were expressed as a \% by weight in oxide form. The carbon content was estimated by measuring the loss on ignition (LOI). The mineral composition of the bauxite and the raw and pyro-processed RM were studied with X-Ray diffraction (XRD), using a Phillips PW1720 XRD with a PW1050/80 goniometer and a PW3313/20 Cu k-alpha anode tube at 40kV and 20mA. All measurements were taken from 3 to 60 degrees $(2 \theta)$ at a step size of 0.02 degrees/second. The particle size was analysed with a laser system using a Malvern Mastersizer 2000 based on laser diffraction. The specific surface area (SSA) was measured using a Quantachrome Nova 4200e apparatus and the Brunauer-Emmett-Teller BET theory, which relates the physical adsorption of gas molecules on the RM particles surface with their specific surface area. The variation of the SSA on pyro-processing was also determined. A known mass of solid sample was purified of all adsorbed gases and water by degassing under vacuum. The samples were then cryogenically cooled, with liquid nitrogen, and the amount of gas adsorbed at varying pressures used to construct an isotherm 
from which the SSA was calculated. Thermal analyses of the raw RM were performed using thermogravimetric analysis (TGA) and differential scanning calorimetry (DSC). Refractory aluminum crucibles were used for the TGA and DSC analyses. They were filled manually and calcined, at the aforementioned temperatures, in a fibre-chamber, $10 \mathrm{~L}$ furnace $\left(1300^{\circ} \mathrm{C}\right)$.

\subsection{Water Demand and Setting Times}

The water demand of the raw and the sintered RM was assessed by measuring the water required by lime/RM pastes to reach a specific flow diameter which was fixed at $170 \pm 5 \mathrm{~mm}$ because it provided a good workability. This water content was used for the mechanical strength tests. The initial flow was measured in accordance with EN 459-2 for 1:1 (lime: RM) pastes.

The rate of stiffening of the RM/lime pastes was measured by dropping a needle from a fixed height and measuring its penetration using the Vicat test. The method in EN 459-2 was followed so that the initial and final setting times are standard references which provide comparative data. The setting (or initial loss of plasticity) of the RM/lime pastes is determined by the evaporation of the mixing water, the carbonation of the lime, and the formation of hydrates. The setting time test was carried out using lime: RM specimens at 1:1 ratio.

\subsection{Reactivity by the Activity Index or Mechanical Method}

Reactivity indicates how quickly a pozzolanic material would combine lime (calcium hydroxide) to form cementing hydrates that would induce setting and eventually hardening. The mechanical method measures reactivity by monitoring the compressive strength of a lime: pozzolan mix in relation to a standard lime mix, at constant water content, over 28 days. However, a fixed water content was not possible as the water demand slightly varied with the sintering temperature. Therefore, the RMs were mixed to flow as explained above. The prisms $160 \times 40 \times 40 \mathrm{~mm}$ were demoulded after 1 day and stored in a curing room at a temperature $20^{\circ} \mathrm{C} \pm \mathrm{H} 3^{\circ} \mathrm{C}$ under damp hessian to maintain humidity at c.95\%. For all the strength tests and mechanical indices, six specimens of each mix were tested for compressive strength and three for flexural strength.

\subsection{Reactivity by the Chapelle Method}

This estimates the pozzolanic activity by measuring the amount of calcium hydroxide fixed by the pozzolanic material (pozzolanic index). Other well know pozzolanic (FA) and cementitious materials (GGBS) previously studied by the authors were also included in the test in order to compare the results. The measurements were performed, in both the raw and the pyroprocessed RM, according to the methods in Berenguer et al [17]; Filho et al [18]; NBR 15895 [19]. The RM was mixed with lime and distilled water, and a blank test containing only calcium oxide was also included. Sucrose is added and stirred into this solution. The resultant solution is titrated with $0.1 \mathrm{M} \mathrm{HCl}$ and the $\mathrm{HCl}$ volume consumed in titration $\left(\mathrm{V}_{2}\right)$ noted. The same procedure was performed with blank assay, noting the volume spent $\left(\mathrm{V}_{3}\right)$. The pozzolanic activity index $\left(\mathrm{I} \mathrm{Ca}(\mathrm{OH})_{2}\right)$ is calculated with equation (1), as the amount of calcium hydroxide $(\mathrm{mg})$ fixed per gram of pozzolanic material:

$$
I_{\mathrm{Ca}(\mathrm{OH})_{2}}=\frac{28\left(V_{3}-V_{2}\right) F C}{m_{2}}
$$


where: $\mathrm{m}_{2}$ is the mass of $\mathrm{R} \mathrm{M}(\mathrm{g}), \mathrm{V}_{2}$ is $\mathrm{HCl} 0.1 \mathrm{M}$ volume consumed by titration $(\mathrm{ml}), \mathrm{V}_{3}$ is the $\mathrm{HCl} 0.1$ $\mathrm{M}$ volume consumed in the blank test, $\mathrm{Fc}$ is a correction factor $\mathrm{FC}=1.32$ - for a $\mathrm{HCl}$ concentration of $0.1 \mathrm{M})$.

\subsection{Phase Transformation and Specific Surface Area Transformation on Pyro-Processing of the RM}

The RM was calcined in an electric furnace at temperatures ranging from 200 to $1000^{\circ} \mathrm{C}$. The calcination was undertaken in small batches and the sintering time was kept constant at 3 hours. The crystalline phases produced as a result of the pyro-processing of the RM were determined with $\mathrm{XRD}$ analysis. The variation of the specific surface area with raising temperature was measured with the Brunauer-Emmett-Teller BET theory as explained above for the raw RM.

\subsection{Microstructure and Hydrate Formation by Scanning Electron Microscopy (SEM) and Energy Dispersive X-Ray Analysis (EDXRA)}

A SEM system was used to investigate the microstructure of the lime/RM pastes and the presence of hydrates. The elemental composition of the newformed hydrates was determined with EDXRA. The qualitative nature of the microscopic study did not provide enough resolution to establish clear differences in the nature of the phases formed upon hydration or the quality and distribution of the hydrates in the different RM pastes. However, some trends could be established, and representative hydrates are shown in the SEM micrographs in the results.

\section{Results}

\subsection{Chemical Composition of the RM}

As noted by previous authors, the chemical composition of the RM is auspicious for the formation of cementing materials, having high silica and alumina contents (table 1). The Saudi RM has a high $\mathrm{SiO}_{2}$ when compared with other RMs (table 2), and the content of chloride is low despite the use of sea water. The calcium content is high when compared with the parent bauxite due to the use of lime during the refining process. The USA does not approve of the use of RM waste because the Environmental Protection Agency identified high levels of arsenic and chromium in some RM samples [20]. However, as it can be seen from Table 1, the levels of arsenic and chromium or any heavy metals in the Saudi RM are low, and hence no environmental toxicity is inferred from the chemistry of the Saudi RM. The only downside of the Saudi RM chemistry seems to be its high alkalinity when compared with other alumina plants where $\mathrm{Na}_{2} \mathrm{O}$ usually varies between 3 and $11 \%$ wt\% (tables 1 and 2). This is probably due to the use of sea water for dust control. 
Table 1 Chemical composition of the red mud and the parent bauxite as a \% by wt oxide.

\begin{tabular}{|c|c|c|c|c|c|c|c|c|c|c|c|c|c|c|c|}
\hline & $\mathrm{SiO}_{2}$ & $\mathrm{Al}_{2} \mathrm{O}_{3}$ & $\mathrm{CaO}$ & $\mathrm{Fe}_{2} \mathrm{O}_{3}$ & $\mathrm{Na}_{2} \mathrm{O}$ & $\mathrm{K}_{2} \mathrm{O}$ & $\mathrm{MgO}$ & $\mathrm{P}_{2} \mathrm{O}_{5}$ & $\mathrm{SO}_{3}$ & $\mathrm{Cl}$ & $\mathrm{TiO}_{2}$ & MnO & CuO & SrO & $\mathrm{ZrO}_{2}$ \\
\hline Red & 19.66 & 29.79 & 5.09 & 12.97 & 24.05 & 0.09 & 0.40 & 0.29 & 1.65 & 0.32 & 5.12 & 0.02 & 0.00 & 0.14 & - \\
\hline \multicolumn{16}{|l|}{ Mud** } \\
\hline bauxite & 26.82 & 54.03 & 2.48 & 6.02 & 0.00 & 0.23 & 0.00 & 0.59 & 2.89 & 0.26 & 5.63 & 0.01 & 0.03 & 0.16 & 0.38 \\
\hline bauxite $^{a}$ & 14.85 & 52.53 & 1.15 & 4.00 & 0.19 & 0.06 & 0.13 & 0.13 & 1.57 & - & 4.78 & $<0.01$ & - & - & - \\
\hline
\end{tabular}

Table 2 Composition of the Saudi RM subject to study compared with other RMs generated from different alumina plants in various countries [10, 21].

\begin{tabular}{llllllll}
\hline Country & Producer & \multicolumn{9}{l}{ Major composition $(\mathbf{w t} . \%)$} & & \\
& & $\mathrm{Fe}_{2} \mathrm{O}_{3}$ & $\mathrm{Al}_{2} \mathrm{O}_{3}$ & $\mathrm{TiO}_{2}$ & $\mathrm{SiO}_{2}$ & $\mathbf{N a}_{2} \mathrm{O}$ & $\mathrm{CaO}$ \\
\hline KSA & MA'ADEM & 12.9 & 29.7 & 5.1 & 19.6 & 24.0 & 5.1 \\
India & HINDALCO & 33.1 & 18.2 & 19.6 & 8.8 & 5.8 & 2.7 \\
India & NARCO & 51.0 & 18.0 & 9.8 & 4.6 & 5.3 & 1.8 \\
Italy & Eurallumina & 35.2 & 20.0 & 9.2 & 11.6 & 7.5 & 6.7 \\
Turkey & Seydisehir & 36.9 & 20.3 & 4.9 & 15.7 & 10.1 & 2.2 \\
Greece & Al de Grece & 40.8 & 19.9 & 5.8 & 6.8 & 2.7 & 12.6 \\
Canada & ALCAN & 31.6 & 20.6 & 6.2 & 8.8 & 10.2 & 1.6 \\
China & - & 27.9 & 22.0 & 2.3 & 20.9 & 10.5 & 6.2 \\
China & Henan & 11.7 & 25.4 & 4.1 & 20.0 & 6.5 & 13.9 \\
China & Shandong & 13.6 & 7.02 & 2.1 & 18.1 & 2.3 & 42.2 \\
Australia & AWAAK & 28.5 & 24.0 & 3.1 & 18.8 & 3.4 & 5.2 \\
Australia & QAL & 30.7 & 18.6 & 7.0 & 16.0 & 8.6 & 2.5 \\
Germany & AOSG & 44.8 & 16.2 & 12.3 & 5.4 & 4.0 & 5.2 \\
Spain & Alcoa & 37.5 & 21.2 & 11.4 & 4.4 & 3.6 & 5.5 \\
Spain & San Ciprián & 39.2 & 19.8 & 10.0 & 8.7 & 5.0 & 4.0 \\
Brazil & Alunorte & 38.0 & 19.0 & 3.8 & 19.9 & 8.5 & 0.8 \\
Brazil & São Paulo & 27.0 & 22.8 & 2.9 & 19.1 & 8.0 & 2.1 \\
USA & RMC & 35.5 & 18.4 & 6.3 & 8.5 & 6.1 & 7.7 \\
\hline
\end{tabular}

\subsection{Physical Properties}

According to the results (Table 3), the RM presents abundant specific surface area (SSA) available for reaction, superior to commercial Portland cement (CEM II) and other pozzolanic and supplementary cements such as FA (fly ash) and GGBS (ground granulated blast-furnace slag). The superior SSA of the RM is an outstanding quality with respect to reactivity, as it is widely accepted that reactivity increases proportionally to the specific surface available for reaction. 
Table 3 Specific surface area and particle size distribution of the RM compared with PC (CEM II) and other supplementary cementitious materials including GGBS and FA

\begin{tabular}{|c|c|c|c|c|c|c|c|c|c|}
\hline & specific & specific & particle & Particle Size & istributio & & & LOI \% & \\
\hline & $\begin{array}{l}\text { surface } \\
\text { area (SSA) } \\
\mathrm{m}^{2} / \mathrm{g}\end{array}$ & $\begin{array}{l}\text { surface } \\
\text { area (SSA) } \\
\mathrm{m}^{2} / \mathrm{kg}\end{array}$ & $\begin{array}{l}\text { density } \\
\mathrm{mg} / \mathrm{m}^{3}\end{array}$ & A.mean $\mu \mathrm{m}$ & $\mathrm{D} 90 \mu \mathrm{m}$ & $\mathrm{D} 50 \mu \mathrm{m}$ & $\mathrm{D} 10 \mu \mathrm{m}$ & $450^{\circ} \mathrm{C}$ & $1000^{\circ} \mathrm{C}$ \\
\hline RM & 9.35 & 9357 & 2.94 & & 8.42 & 3.80 & 0.40 & 5.04 & 11.51 \\
\hline GGBS & 1.95 & 1950 & 1.80 & 18 & 31.62 & 11.67 & 2.35 & 0.41 & -0.77 \\
\hline FA & 6.50 & 6500 & 2.28 & 15 & 100.63 & 14.96 & 1.95 & 1.67 & 4.92 \\
\hline CEM II & 1.88 & 1880 & - & - & 82.58 & 24.90 & 2.56 & - & - \\
\hline
\end{tabular}

The carbon content of the Saudi RM is either comparable or lower than others previously studied (Table 4). This constitutes a good quality with respect to reactivity, as it is well known that a high LOI (carbon content) adversely affects reactivity and increases water demand, and that it is associated to lowering strength and enhancing fracturing which could accelerate carbonation, chemical attack and the corrosion of embedded steel reinforcement. The negative value indicates that the GGBS absorbed some moisture during testing.

Table 4 Carbon content of the Saudi RM compared with others previously studied.

\begin{tabular}{lll}
\hline Country & Reference & LOI \\
\hline Belgium & {$[22]$} & 10.20 \\
France & {$[23]$} & 10.77 \\
Canada & {$[24]$} & 10.51 \\
China & {$[25]$} & 17.42 \\
Minas Gerais & {$[13]$} & 13.00 \\
China & {$[10]$} & 20.07 \\
Korea & {$[26]$} & 9.10 \\
China & {$[27]$} & 13.74 \\
\hline
\end{tabular}

\subsection{Mineral Composition}

The mineralogical composition of the parent bauxite is included in Table 5. According to the XRD results, the bauxite consists of kaolinite, boehmite and gibbsite (major phases: 40-15\%) while gypsum, rutile/anatase and magnetite are minor components (15-7\%), and there are traces of goethite. The mineral composition of the RM appears in Table 5 and Figure 1 . It is evident that gibbsite, boehmite and rutile are inherited from the bauxite ore, and that cancrinite, sodalite, chantalite, hematite and calcite have formed during the Bayer process. 
Table 5 Mineral composition of the bauxite ore and the RM residue determined with XRD.

\begin{tabular}{|c|c|c|c|}
\hline \multirow[t]{2}{*}{ Material } & \multicolumn{3}{|l|}{ Mineral composition by XRD } \\
\hline & \multicolumn{3}{|c|}{ major phases (40-15\%) subsidiary (15-7\%) traces $<7 \%$} \\
\hline \multirow[t]{3}{*}{ Bauxite } & Kaolinite $-\mathrm{Al}_{2} \mathrm{Si}_{2} \mathrm{O}_{5}(\mathrm{OH})_{4}$ & Gypsum - $\mathrm{CaSO}_{4} \cdot 2 \mathrm{H}_{2} \mathrm{O}$ & Goethite $\mathrm{Fe}_{2} \mathrm{O}_{3} \cdot \mathrm{H}_{2} \mathrm{O}$ \\
\hline & Gibbsite - Al $(\mathrm{OH})_{3}$ & Rutile/anatase $-\mathrm{TiO}_{2}$ & \\
\hline & Boehmite - $\curlyvee$ - AlO $(\mathrm{OH})$ & Magnetite $-\mathrm{Fe}_{2} \mathrm{O}_{4}$ & \\
\hline \multirow[t]{5}{*}{ RM } & Hematite $-\mathrm{Fe}_{2} \mathrm{O}_{3}$ & Boehmite $-\curlyvee-\mathrm{AlO}(\mathrm{OH})$ & Quartz $\mathrm{SiO}_{2}$ \\
\hline & Cancrinite - & Calcite $\mathrm{CaCO}_{3}$ & Rutile $\mathrm{TiO}_{2}$ \\
\hline & $\mathrm{Na}_{6} \mathrm{Ca}_{2}\left[\left(\mathrm{CO}_{3}\right)_{2} \mid \mathrm{Al}_{6} \mathrm{Si}_{6} \mathrm{O}_{24}\right] \cdot 2 \mathrm{H}_{2} \mathrm{O}$ & & Goethite $\alpha-\mathrm{FeOOH}$ \\
\hline & Gibbsite - $\mathrm{Al}(\mathrm{OH})_{3}$ & & Chantalite - $\mathrm{CaAl}_{2}\left(\mathrm{SiO}_{4}\right)(\mathrm{OH})_{4}$ \\
\hline & Sodalite $\mathrm{Na}_{4} \mathrm{Si}_{3} \mathrm{Al}_{3} \mathrm{O}_{12} \mathrm{Cl}$ & & \\
\hline
\end{tabular}

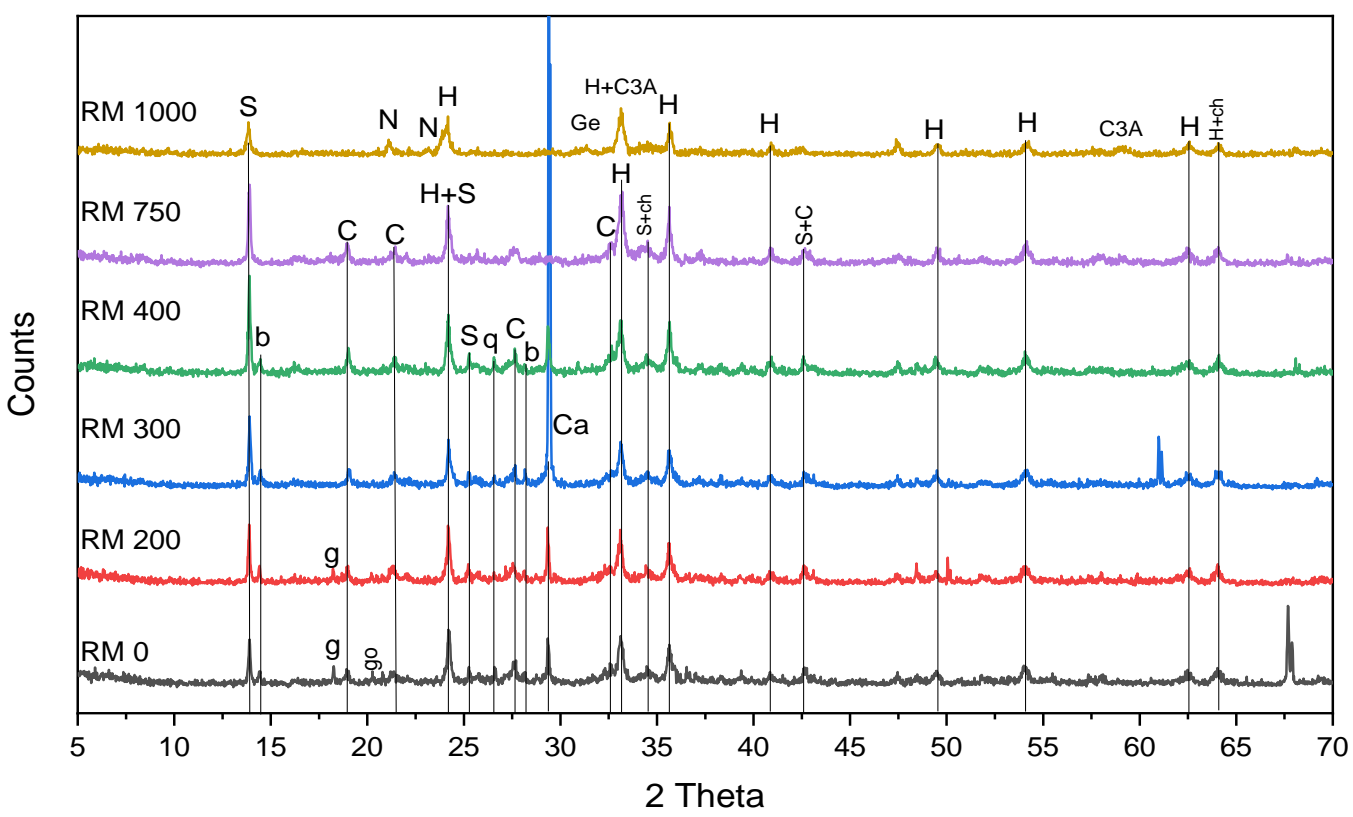

S-Sodalite b-Boehmite C-Cancrinite N-nepheline H- Hematite Ge-Gehlenite C3A- Tricalcium Aluminate q- Quartz g-Gibbsite go-Goethite ch- Chantalite

Figure 1 Phase transformation on pyro-processing of the RM.

In the $\mathrm{RM}$, the kaolinite from the parent bauxite has reacted with the $\mathrm{NaOH}$ and carbonated with the lime in the refining process, transforming into feldespathoids cancrinite and sodalite. This agrees with previous literature stating that kaolinite is not stable under highly alkaline conditions and various zeolite and feldspathoids can form [28]. The transformation of kaolinite into cancrinite during the Bayer process agrees with Zhao et al [29], who obtained feldespathoids cancrinite and sodalite by reacting kaolinite with alkali solutions. Cancrinite is considered a feldspathoid rather than a zeolite due to the difficulty of molecular diffusion in its framework [29]. Similarly, sodalite is a tectosilicate without zeolitic water. The identification of cancrinite and sodalite in RM can be difficult. They have several common peaks located at $6.32,3.65,2.59$ and $2.11 \AA$, but cancrinite can be identified by its characteristic diffraction peaks at 3.24, 2.74, 4.69 and $4.15 \AA$ [29]. In the Saudi 
RM, sodalite's unique peak at $2.84 \AA$ A and other characteristic peaks at 4.46 and $4.00 \AA$ are concealed, but other characteristic and intense peaks such as 3.52 and $6.39 \AA$ are evident.

The mineral composition of the Saudi RM also agrees with Castaldi et al. [30] who reported the presence of cancrinite, hematite and sodalite making up 78\% wt of the RM (with cancrinite and sodalite accounting for c.50\%) and amorphous oxides accounting for 15-20\% wt. However, the halo and the lifting of the trace indicating the presence of amorphous phases is minor in the Saudi RM indicating a higher crystallinity (Figure 1). The composition also agrees with Klauber et al [8] who found cancrinite, sodalite, dawsonite, and calcium-containing phases resulting from the Bayer process. The gibbsite $\left(\mathrm{Al}(\mathrm{OH})_{3}\right)$ and boehmite $(\mathrm{\gamma}$-AlOOH) in the Saudi RM are undigested bauxite material, and the original goethite has been converted to hematite as previously highlighted by Klauber et al [8]. The use of lime (twice) in the Maa'dem refining process, has facilitated the occurrence of cancrinite, chantalite and calcite in the Saudi RM, and has also assisted the transformation of the original bauxite iron compounds (goethite and magnetite) into hematite.

\subsection{Phase Transformation on Pyro-Processing}

The mineral phases produced when the RM was sintered at increasing temperature were determined with XRD analysis and are included in Table 6 and Figure 1. The main phase changes are as follows:

Table 6 Phase evolution and mineralogical changes on pyro-processing of the RM determined with XRD.

\begin{tabular}{|c|c|c|c|c|}
\hline \multirow[t]{2}{*}{ Material } & \multicolumn{3}{|l|}{ Mineral composition by XRD } & \multirow[t]{2}{*}{ Phase changes } \\
\hline & major phases (40-15\%) subsidi & ry $(15-7 \%)$ traces $<7 \%$ & & \\
\hline $\begin{array}{l}\mathrm{RM} 0^{\circ} \mathrm{C}- \\
200^{\circ} \mathrm{C}\end{array}$ & $\begin{array}{l}\text { Hematite }-\mathrm{Fe}_{2} \mathrm{O}_{3} \\
\text { Cancrinite } \\
\mathrm{Na}_{6} \mathrm{Ca}_{2}\left[\left(\mathrm{CO}_{3}\right)_{2} \mid \mathrm{Al}_{6} \mathrm{Si}_{6} \mathrm{O}_{24}\right] \cdot 2 \mathrm{H}_{2} \mathrm{O} \\
\text { Gibbsite }-\mathrm{Al}(\mathrm{OH})_{3} \\
\text { Sodalite }-\mathrm{Na}_{4} \mathrm{Si}_{3} \mathrm{Al}_{3} \mathrm{O}_{12} \mathrm{Cl}\end{array}$ & $\begin{array}{l}\text { Boehmite }-\curlyvee-\mathrm{AlO}(\mathrm{OH}) \\
\text { Calcite }-\mathrm{CaCO}_{3}\end{array}$ & $\begin{array}{l}\text { Quartz - } \mathrm{SiO}_{2} \\
\text { Rutile } \mathrm{TiO}_{2} \\
\text { Goethite } \\
\text { a-FeOOH } \\
\text { Chantalite } \\
\mathrm{CaAl}_{2}\left(\mathrm{SiO}_{4}\right)(\mathrm{OH})_{4}\end{array}$ & $\begin{array}{l}\text {-No appreciable } \\
\text { changes in mineral } \\
\text { composition } \\
\text { between } 0 \text { and } 200 \\
\text { degrees. } \\
\text {-Cancrinite increases } \\
\text { up to } 400^{\circ} \mathrm{C} \text {, then it } \\
\text { lowers. }\end{array}$ \\
\hline RM & Hematite & Boehmite $-\curlyvee$ - AlO $(\mathrm{OH})$ & Chantalite & -Gibbsite has \\
\hline $300^{\circ} \mathrm{C}$ & $\begin{array}{l}\mathrm{Fe}_{2} \mathrm{O}_{3} \\
\text { Cancrinite } \\
\mathrm{Na}_{6} \mathrm{Ca}_{2}\left[\left(\mathrm{CO}_{3}\right)_{2} \mid \mathrm{Al}_{6} \mathrm{Si}_{6} \mathrm{O}_{24}\right] \cdot 2 \mathrm{H}_{2} \mathrm{O} \\
\text { Sodalite - } \mathrm{Na}_{4} \mathrm{Si}_{3} \mathrm{Al}_{3} \mathrm{O}_{12} \mathrm{Cl}\end{array}$ & Calcite- $\mathrm{CaCO}_{3}$ & $\mathrm{CaAl}_{2}\left(\mathrm{SiO}_{4}\right)(\mathrm{OH})_{4}$ & $\begin{array}{l}\text { disappeared. } \\
\text { Likely turned into } \\
\text { boehmite. }\end{array}$ \\
\hline RM & Hematite $\mathrm{Fe}_{2} \mathrm{O}_{3}$ & Boehmite $\curlyvee$ - AlO $(\mathrm{OH})$ & Chantalite & -Maximum \\
\hline $400^{\circ} \mathrm{C}$ & $\begin{array}{l}\text { Cancrinite } \\
\mathrm{Na}_{6} \mathrm{Ca}_{2}\left[\left(\mathrm{CO}_{3}\right)_{2} \mid \mathrm{Al}_{6} \mathrm{Si}_{6} \mathrm{O}_{24}\right] \cdot 2 \mathrm{H}_{2} \mathrm{O} \\
\text { Sodalite }-\mathrm{Na}_{4} \mathrm{Si}_{3} \mathrm{Al}_{3} \mathrm{O}_{12} \mathrm{Cl}\end{array}$ & Calcite $\mathrm{CaCO}_{3}$ & $\mathrm{CaAl}_{2}\left(\mathrm{SiO}_{4}\right)(\mathrm{OH})_{4}$ & $\begin{array}{l}\text { cancrinite content. } \\
\text {-Chantalite slightly } \\
\text { increases. }\end{array}$ \\
\hline
\end{tabular}




\begin{tabular}{|c|c|c|c|c|}
\hline $\begin{array}{l}\mathrm{RM} \\
750^{\circ} \mathrm{C}\end{array}$ & $\begin{array}{l}\text { Hematite } \mathrm{Fe}_{2} \mathrm{O}_{3} \\
\text { Cancrinite } \\
\mathrm{Na}_{6} \mathrm{Ca}_{2}\left[\left(\mathrm{CO}_{3}\right)_{2} \mid \mathrm{Al}_{6} \mathrm{Si}_{6} \mathrm{O}_{24}\right] \cdot 2 \mathrm{H}_{2} \mathrm{O} \\
\text { Sodalite - } \mathrm{Na}_{4} \mathrm{Si}_{3} \mathrm{Al}_{3} \mathrm{O}_{12} \mathrm{Cl}\end{array}$ & Perovskite - Ca $\mathrm{Ti} \mathrm{O}_{3}$ & $\begin{array}{l}\text { Chantalite } \\
\mathrm{CaAl}_{2}\left(\mathrm{SiO}_{4}\right)(\mathrm{OH})_{4}\end{array}$ & $\begin{array}{l}\text {-Boehmite, sodalite } \\
\text { and calcite } \\
\text { disappear. } \\
\text { - Chantalite lowers. } \\
\text { - Significant } \\
\text { cancrinite. }\end{array}$ \\
\hline $\begin{array}{l}\mathrm{RM} \\
1000^{\circ} \mathrm{C}\end{array}$ & $\begin{array}{l}\text { Hematite } \mathrm{Fe}_{2} \mathrm{O}_{3} \\
\text { Sodalite - } \mathrm{Na}_{4} \mathrm{Si}_{3} \mathrm{Al}_{3} \mathrm{O}_{12} \mathrm{Cl}\end{array}$ & $\begin{array}{l}\text { Nepheline } \mathrm{Na} \mathrm{Al} \mathrm{SiO}_{4} \\
\mathrm{C}_{3} \mathrm{~A} \text {-Tricalcium } \\
\text { aluminate-Ca } \mathrm{Al}_{2} \mathrm{O}_{4}\end{array}$ & $\begin{array}{l}\text { Gehlenite- } \\
\mathrm{Ca}_{2} \mathrm{Al}_{2} \mathrm{SiO}_{7}\end{array}$ & $\begin{array}{l}\text { - Cancrinite and } \\
\text { chantalite disappear. }\end{array}$ \\
\hline
\end{tabular}

- At $300^{\circ} \mathrm{C}$. Gibbsite has disappeared turning into boehmite, and likely amorphous alumina polymorphs. Only boehmite was clearly detected, however, some amorphous alumina polymorphs are probably present because the evolution of the XRD trace halo and the slight lifting of the base-line roughly indicate that the RM is most amorphous at $300^{\circ} \mathrm{C}$. These changes agree with previous authors reporting the decomposition of gibbsite and the beginning and evolution of gibbsite dehydroxilation to form both boehmite and amorphous alumina polymorphs [31-33]. However, the temperature at which gibbsite disappears is lower in the Saudi RM. Sglavo et al [15] state that the transformation of aluminium hydroxide phases (Bayerite, Gibbsite and Boehmite) into alumina polymorphs is the most important phenomenon up to $800^{\circ} \mathrm{C}$, but in the Saudi RM, the decomposition of gibbsite takes place at a significantly lower temperature $\left(<300^{\circ} \mathrm{C}\right)$.

- At $400^{\circ} \mathrm{C}$, the maximum cancrinite is recorded.

- At $750^{\circ} \mathrm{C}$ boehmite, sodalite and calcite have disappeared and chantalite lowers, but there is still significant cancrinite.

- At $1000^{\circ} \mathrm{C}$ cancrinite and chantalite disappear forming nepheline, $C_{3} \mathrm{~A}$ and gehlenite. This agrees with Sglavo et al [15] who also found nepheline in RM samples sintered between 900 and $1200^{\circ} \mathrm{C}$. However, the authors report that the decomposition of chantalite and cancrinite produces alkaline oxides which in turn produce incipient nepheline at a slightly lower temperature $\left(\mathrm{c} .800^{\circ} \mathrm{C}\right)$.

\subsection{Thermal Analyses}

The thermogravimetric analysis (TGA- Figure 2) shows a continuous weight loss as the temperature raises up to $1000^{\circ} \mathrm{C}$. The total mass loss of the $\mathrm{RM}$ is $12 \%$ at $1000^{\circ} \mathrm{C}$, it is slow and steady because the samples were previously dried at $100^{\circ} \mathrm{C}$, and as expected, it coincides with the loss on ignition. 


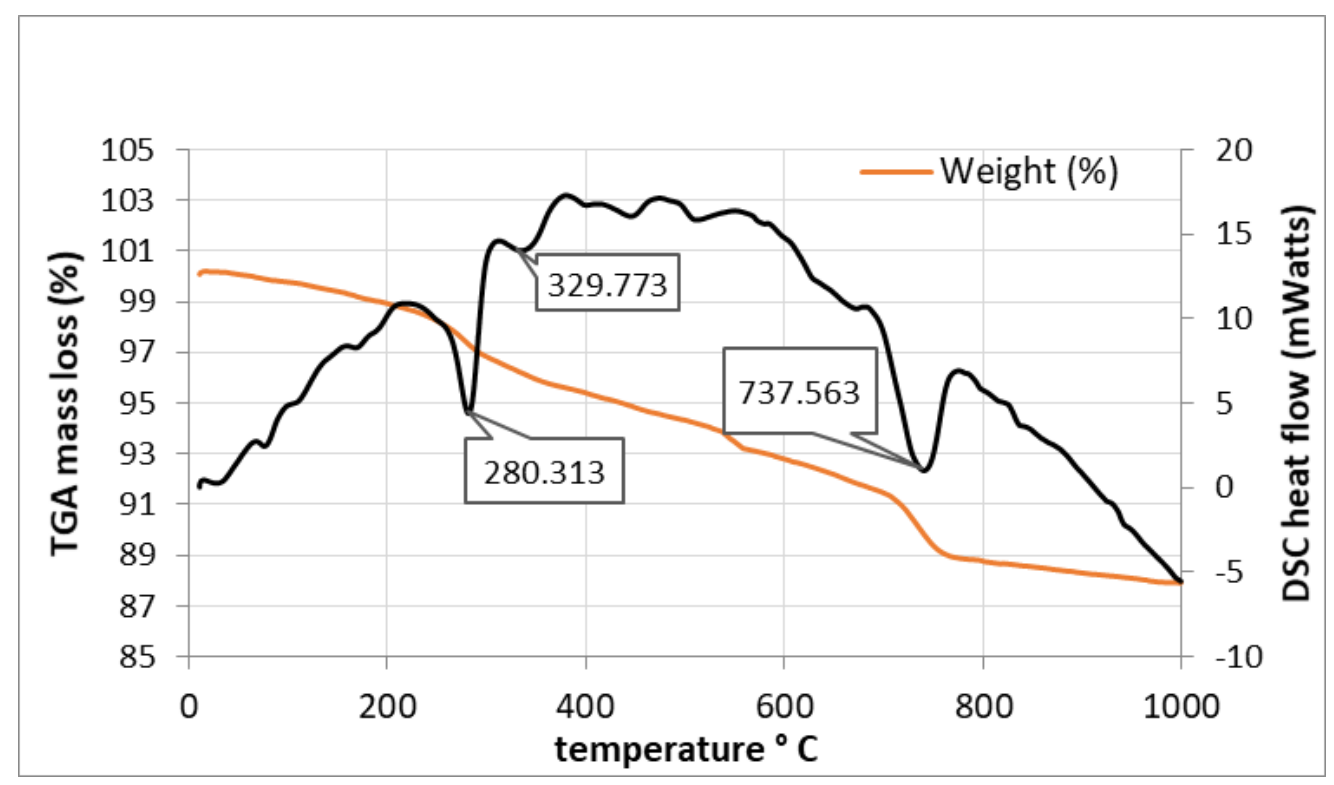

Figure 2 Thermogravimetric and differential scanning calorimetry analyses of the red mud.

The differential scanning calorimetry (DSC- Figure 2) curve shows two marked endothermic peaks at 280 and $737^{\circ} \mathrm{C}$ where the samples take in heat to decompose. The endothermic peak at $280{ }^{\circ} \mathrm{C}$ is usually attributed to the decomposition of gibbsite and the beginning and evolution of gibbsite dehydroxilation (to form both boehmite and $\chi$-alumina according with Atasoy [31]).

The endothermic peak at $737^{\circ} \mathrm{C}$ corresponds to the decomposition of boehmite, sodalite and calcite because, according to the XRD results, at $750^{\circ} \mathrm{C}$, they have disappeared. This agrees with Sglavo et al [15] who claim that the endothermic peak at around $800^{\circ} \mathrm{C}$ is due to the transformation of low temperature aluminium hydroxide phases (bayerite, gibbsite and boehmite) into $\eta-, \chi$ - and $\mathrm{\gamma}-\mathrm{Al}_{2} \mathrm{O}_{3}$. It also agrees with Rivas Mercury et al [34] who attributed this peak and the final descending (endothermic) branch to sodalite decomposition at c. $700^{\circ} \mathrm{C}(965-1523 \mathrm{~K})$. The endothermic DSC peaks are mirrored by two episodes of mass loss which are related to the evaporation of the water mechanically held, the gibbsite dehydroxilation, and the evolution of $\mathrm{CO}_{2}$. These weight losses can also be related to the loss of water molecules located in the channels and cages of cancrinite and sodalite [35].

\subsection{Variation of Specific Surface Area, Water Demand and Setting with Pyro-Processing}

As it can be seen from the results (Table 7), the specific surface area of the RM particles increases as the calcination temperature raises up to $c .700^{\circ} \mathrm{C}$, but after this threshold the surface area lowers. According to the XRD results, the main phase change above $750^{\circ} \mathrm{C}$ is the disappearance cancrinite. Therefore, the lowering of the SSA after $700^{\circ} \mathrm{C}$ is due to the melting and agglomeration of cancrinite. 
Table 7 Variation of specific surface area, water demand and setting times with pyroprocessing. Setting times for 1:1 (RM: Lime) pastes to produce an initial flow of $170 \pm$ $5 \mathrm{~mm}$.

\begin{tabular}{|c|c|c|c|c|c|}
\hline & $\mathrm{T}^{\circ} \mathrm{C}$ & $W / b$ & $\mathrm{SSA}\left(\mathrm{m}^{2} / \mathrm{g}\right)$ & Initial Setting Time (min) & Final Setting Time (min) \\
\hline & 0 & 0.73 & 9.03 & 170 & 180 \\
\hline & 200 & 0.70 & 8.87 & 150 & 130 \\
\hline \multirow[t]{4}{*}{ RM } & 300 & 0.85 & 9.91 & 240 & 260 \\
\hline & 400 & 0.83 & 11.47 & 140 & 150 \\
\hline & 750 & 0.85 & 14.08 & 130 & 160 \\
\hline & 1000 & 0.75 & 2.75 & 110 & 140 \\
\hline \multicolumn{2}{|c|}{ Lime * } & 0.52 & - & 360 & 370 \\
\hline
\end{tabular}

* Hydrated lime of European designation CL90s.

An increase of fineness or surface area raises the water demand to reach a specific consistency. The water demand results agree with the variation of specific surface area, as the water demand increases with the calcination temperature up to $750^{\circ} \mathrm{C}$, and lowers at $1000^{\circ} \mathrm{C}$. These results agree with the mineral composition results placing the maximum content of the cancrinite (a feldspatoid/zeolite characterized by its open microstructure) between 400 and $700^{\circ} \mathrm{C}$.

As it can be seen from Table 7, all the RMs speed up the initial and the final set of the lime significantly. All the RMs reduced final setting time of the lime paste by over $50 \%$ except for the 300 $\mathrm{RM}$ where the reduction is less substantial. The slow set of the RM burned at $300^{\circ} \mathrm{C}$ is inconsistent and it is due to the water content being too high for its SSA. The fastest set is achieved by the RM sintered at 400 and $750^{\circ} \mathrm{C}$. This is consistent with the results above as these RMs have the greatest SSAs. It has been stated that the iron phases control the setting properties and the colour of RMs [10]. This paper disagrees, because the Saudi RM is a pozzolanic material, and the main iron phase (hematite) remains unchanged during the pyro-processing. Therefore, in the RM, the setting (or initial loss of plasticity) is not determined by the iron phases but by the evaporation of the mixing water, the carbonation of the lime, and the formation of pozzolanic hydrates.

\subsection{Reactivity by the Chapelle Test}

According to the Chapelle test results (Table 8), the RM combines the most lime when burned at $400{ }^{\circ} \mathrm{C}$, closely followed by $300{ }^{\circ} \mathrm{C}$. The pozzolanic index values of the RM burned at $400{ }^{\circ} \mathrm{C}$, compare well with some reactive, low-Ca (c.3\%), class $F$ [36], fly ashes (FA) previously studied [37, 38]. As expected, the GGBS pozzolanic index is low, as it is a cementitious material that needs less lime than pozzolans to activate and releases lime on hydration.

Table 8 Pozzolanic index or mg of lime fixed per gram of pozzolanic material $\left(\mathrm{I} \mathrm{Ca}(\mathrm{OH})_{2}\right)$ for the raw and thermally treated RM compared with GGBS and FA.

\begin{tabular}{|c|c|c|c|c|c|c|c|c|c|c|c|}
\hline Materials & RM & RM200 & RM300 & RM400 & RM750 & RM1000 & GGBS** & FA* & $\mathrm{SCBA}^{+}$ & $\mathrm{FA}^{+}$ & $\mathrm{MK}^{+}$ \\
\hline $\mathrm{mg} \mathrm{Ca}(\mathrm{OH})_{2} / \mathrm{g}$ & 251 & 277 & 406 & 457 & 254 & 280 & 209 & 572 & - & - & - \\
\hline $\mathrm{mg} \mathrm{CaO} / \mathrm{g}$ & 190 & 209 & 308 & 346 & 192 & 212 & 158 & 433 & - & - & - \\
\hline
\end{tabular}




\begin{tabular}{llllllllllll}
\hline $\mathrm{Ca}(\mathrm{OH})_{2}$ & 125 & 138 & 203 & 229 & 127 & 140 & 104 & 286 & $\begin{array}{l}293- \\
337\end{array}$ & 382 & 1194 \\
\hline
\end{tabular}

* Alelweet and S. Pavia [38]; ** Alelweet and Pavia [37, 39]; ${ }^{+}$Berenguer et al [17]. MK metakaolin. SCBA-sugar cane bagasse ash.

\subsection{Reactivity by Strength Development (Mechanical Method)}

As it can be seen from the results in Table 9, the $\mathrm{RM}$ sintered at $300^{\circ} \mathrm{C}$ reached the highest mechanical index, closely followed by the RMs sintered at 400,750 and $1000{ }^{\circ} \mathrm{C}$. The reactivity of the RM (measured as the mechanical index at 28 days) is superior to other pozzolanic materials previously studied including Leca (4.6), FA (3.4) and ceramic dusts (1-3), and slightly inferior to microsilica (12.5) and rice husk ash (RHA=12) [40, 41].

Table 9 Compressive and flexural strengths and mechanical indices at 28 days. SDstandard deviation.

\begin{tabular}{lllllll}
\hline RM & $\begin{array}{l}\text { Flexural } \\
\text { strength (MPa) }\end{array}$ & SD & $\begin{array}{l}\text { Compressive } \\
\text { strength (MPa) }\end{array}$ & SD & $\begin{array}{l}\text { Mechanical } \\
\text { index-MI }\end{array}$ & SD \\
\hline RM 0 & 0.73 & 0.10 & 2.02 & 0.25 & 6 & 0.15 \\
RM 200 & 0.62 & 0.05 & 1.96 & 0.30 & 6 & 0.18 \\
RM 300 & 0.86 & 0.06 & 2.50 & 0.19 & 8 & 0.12 \\
RM 400 & 0.87 & 0.14 & 2.09 & 0.20 & 7 & 0.12 \\
RM 750 & 0.85 & 0.09 & 2.02 & 0.20 & 7 & 0.13 \\
RM 1000 & 0.88 & 0.01 & 2.18 & 0.10 & 7 & 0.08 \\
\hline
\end{tabular}

From the long-term strength development results (Table 10) it can be stated that RM completes the pozzolanic reaction earlier that other pozzolans such as FA. The ultimate strength values of the GGBS materials are higher as expected from their cementitious nature.

Table 10 Ultimate strengths and mechanical indices of the RM sintered at $750^{\circ} \mathrm{C}$ compared with FA and GGBS. Standard deviation $=0.13-0.17$. MI- mechanical index.

\begin{tabular}{lllllll}
\hline \multirow{2}{*}{ Material } & \multicolumn{2}{l}{ Compressive strength (MPa) } & \multicolumn{4}{l}{ Flexural strength (MPa) } \\
& 4 month & 5 month & MI & 4 month & 5 month & MI \\
\hline RM 750 & 1.80 & 1.48 & 7.00 & 0.87 & 2.23 & 9.09 \\
FA & 3.43 & 4.55 & 18.56 & 1.82 & 1.93 & 7.88 \\
GGBS & 6.02 & 8.37 & 34.18 & 2.63 & 2.22 & 9.06 \\
\hline
\end{tabular}

\subsection{Microstructure and Presence of Hydrates}

The SEM was used to investigate the quality and distribution of the hydrates in the lime/red mud pastes. The elemental composition of the hydrates was determined with EDXRA. The background search didn't reveal research work to which the results could be compared. The qualitative nature of the SEM analyses did not allow to determine clear differences in the microstructure of the type 
of hydrates produced by the different pastes. However, some trends could be established, and welldefined and representative hydrates are shown in the SEM micrograph results.

At 28 days, the general structure of the 1:1, RM: Lime paste shows abundant hydrates in the RM sintered at $300^{\circ} \mathrm{C}$ (Figure 3 and Figure 4). The chemical composition indicates that these are pozzolanic hydrates resulting from the RM's cancrinite phase (Figure 5 and Figure 6). The morphology and composition of the hydrates is consistent (Figure 7 and Figure 8), and further investigation evidenced fan-shaped sprays of cancrinite crystals and hexagonal plates (Figure 9 and Figure 10). After 3 months of curing, there seems to be a shift toward cubic hydrates (Figures 1214), probably due to the transformation of the metastable hexagonal hydrates. Manfroi et al [13] found calcium silicate hydrate (C-S-H) and C-A-H gel and AFm phase in RM pastes. AFm phases are also found upon pozzolanic reaction in the Saudi RM, however, the main pozzolanic hydrates seem to be of a zeolitic nature. Therefore, the reaction products of the Saudi RM can be better compared with those of natural pozzolans of zeolitic nature [42].

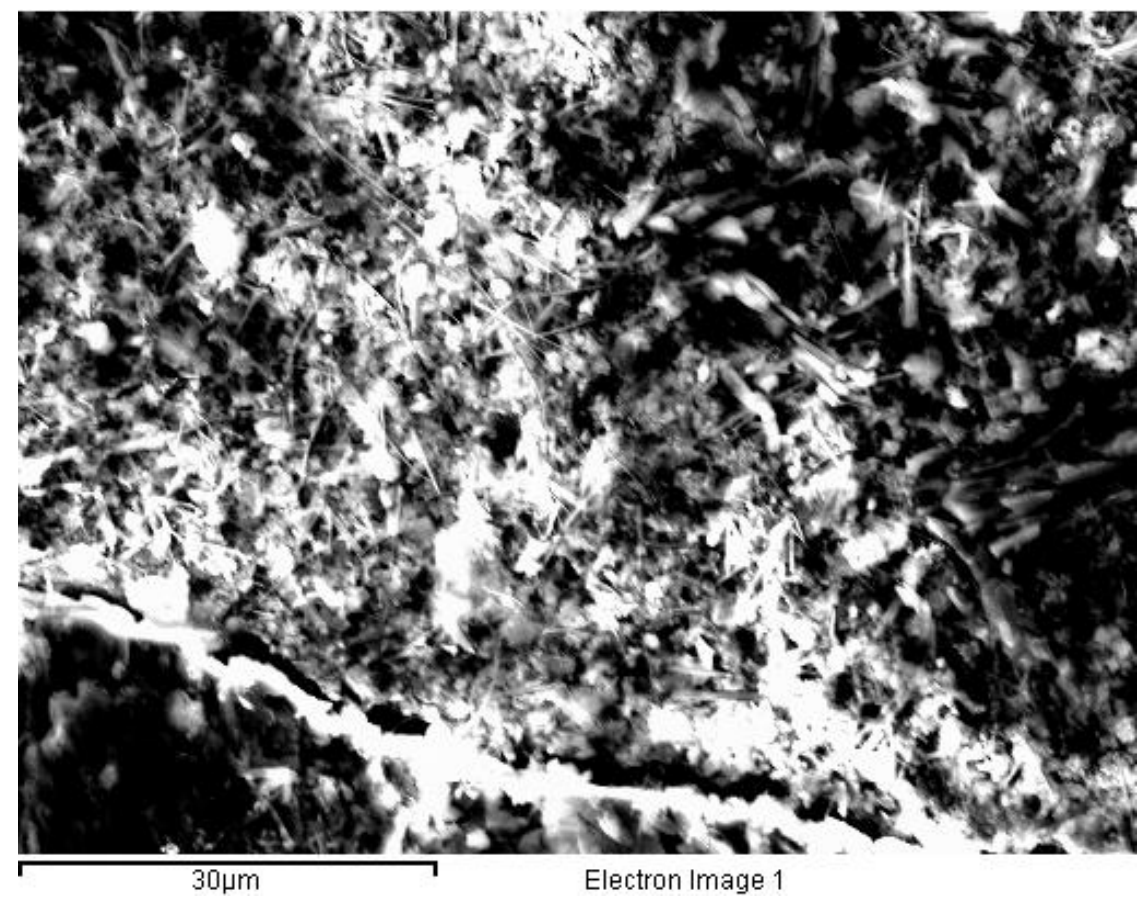

Figure 3 General structure of the 1:1, RM: Lime paste at 28 days showing abundant hydrates (RM sintered at $300^{\circ} \mathrm{C}$ ). 


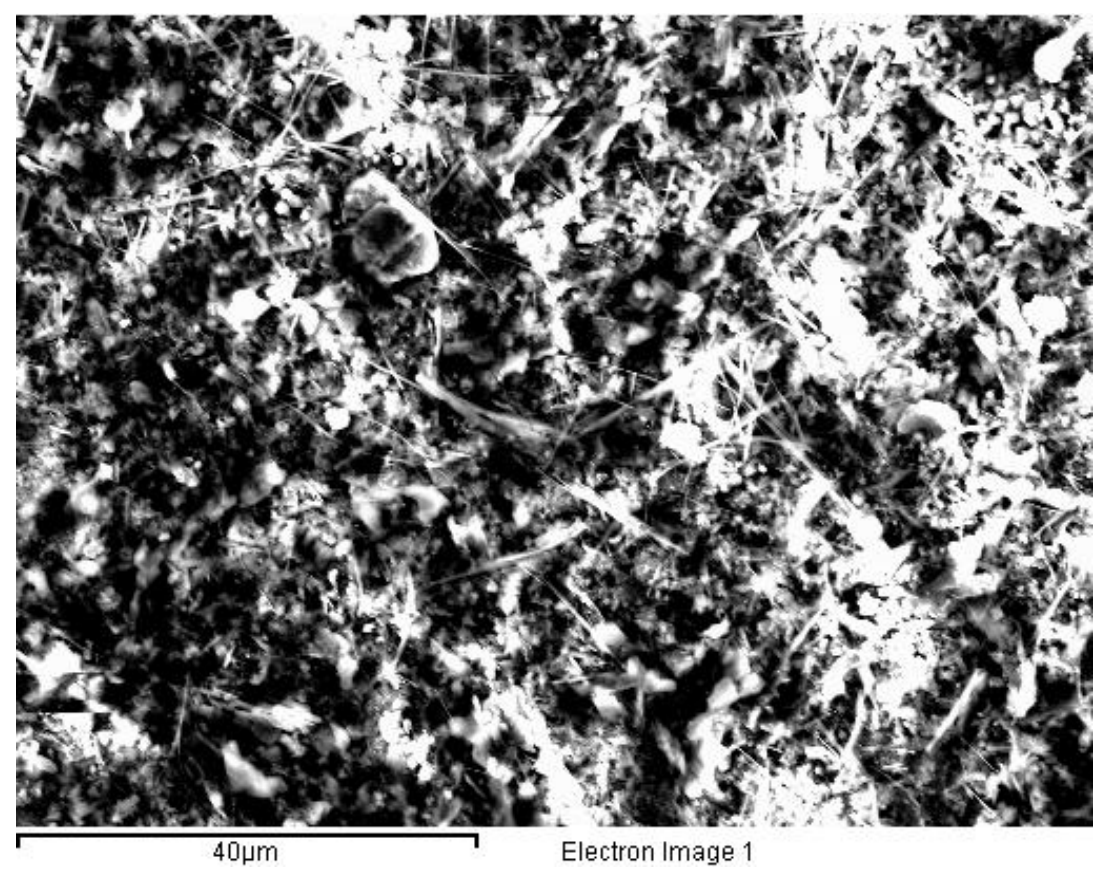

Figure 4 General structure of the 1:1, RM: Lime paste at 28 days showing abundant hydrates (RM sintered at $300^{\circ} \mathrm{C}$ ).

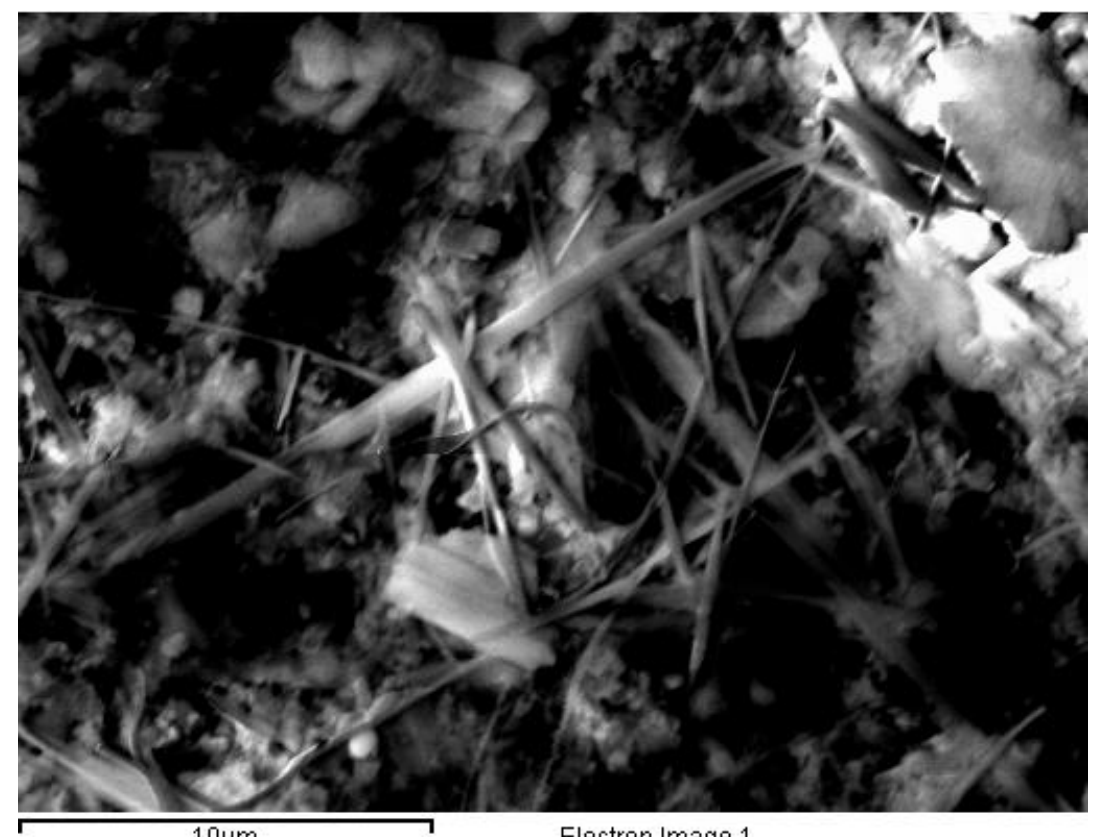

$10 \mu \mathrm{m} \quad$ Electron Image 1

Figure 5 Representative morphology of the hydrates in the RM/lime paste in Figure 4. 


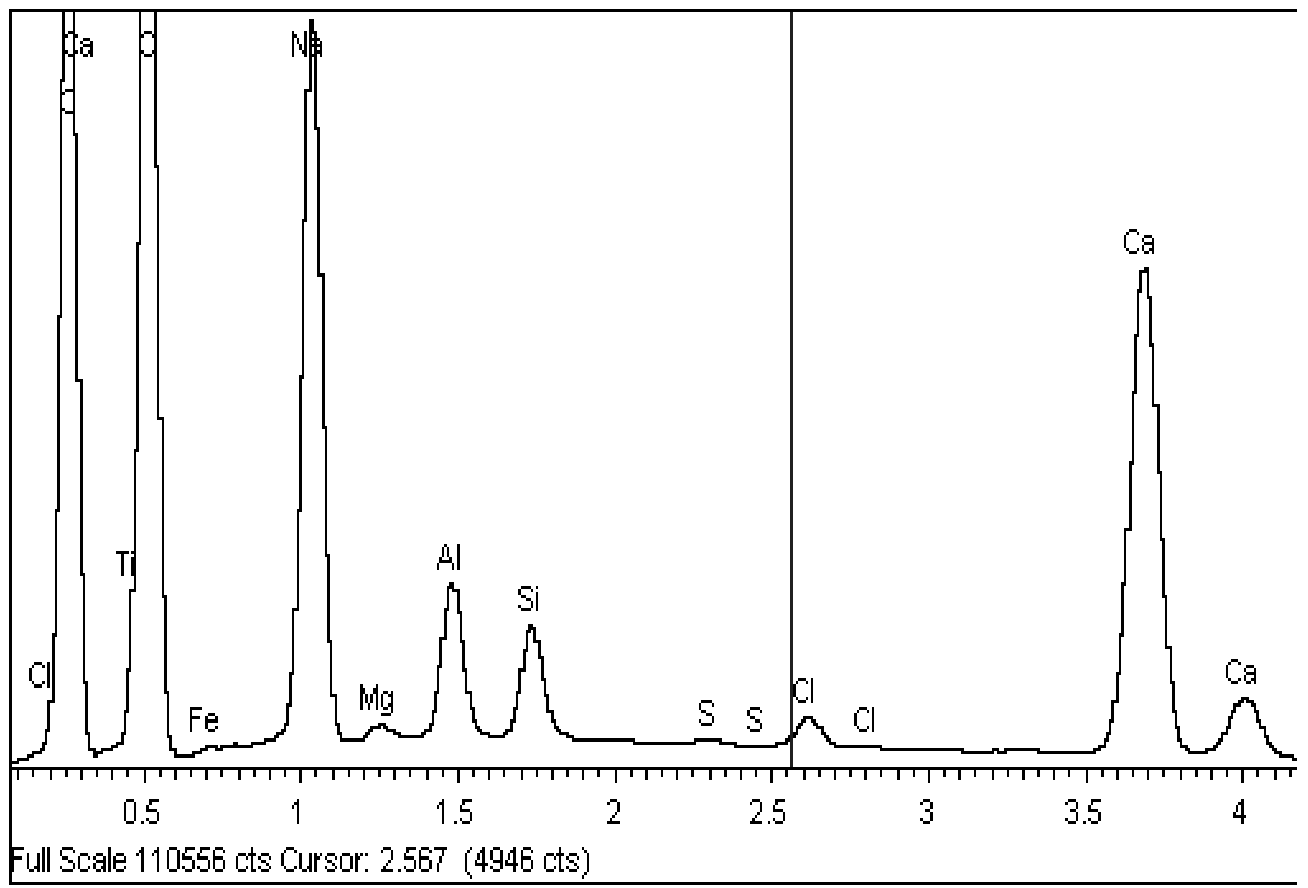

Figure 6 The chemical composition of the hydrates in Figure 5 indicates that these are pozzolanic hydrates derived from the $\mathrm{RM}^{\prime} \mathrm{s}$ cancrinite phase $\left(\mathrm{Na}_{6} \mathrm{Ca}_{2}\left[\left(\mathrm{CO}_{3}\right)_{2} \mid \mathrm{Al}_{6} \mathrm{Si}_{6} \mathrm{O}_{24}\right] \cdot 2 \mathrm{H}_{2} \mathrm{O}\right)$.

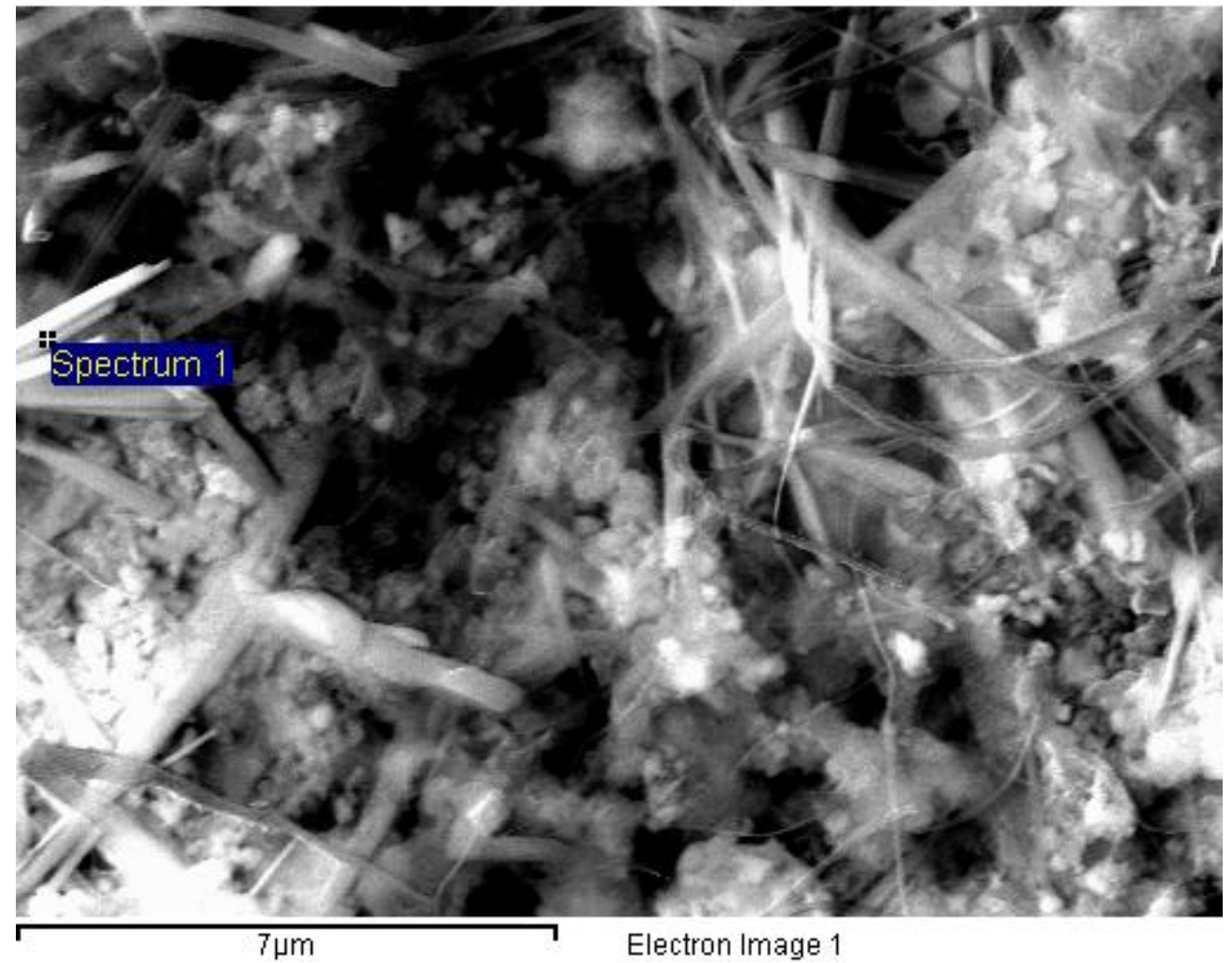

Figure 7 Further detail of the most abundant pozzolanic hydrates found in the RM/lime pastes. 


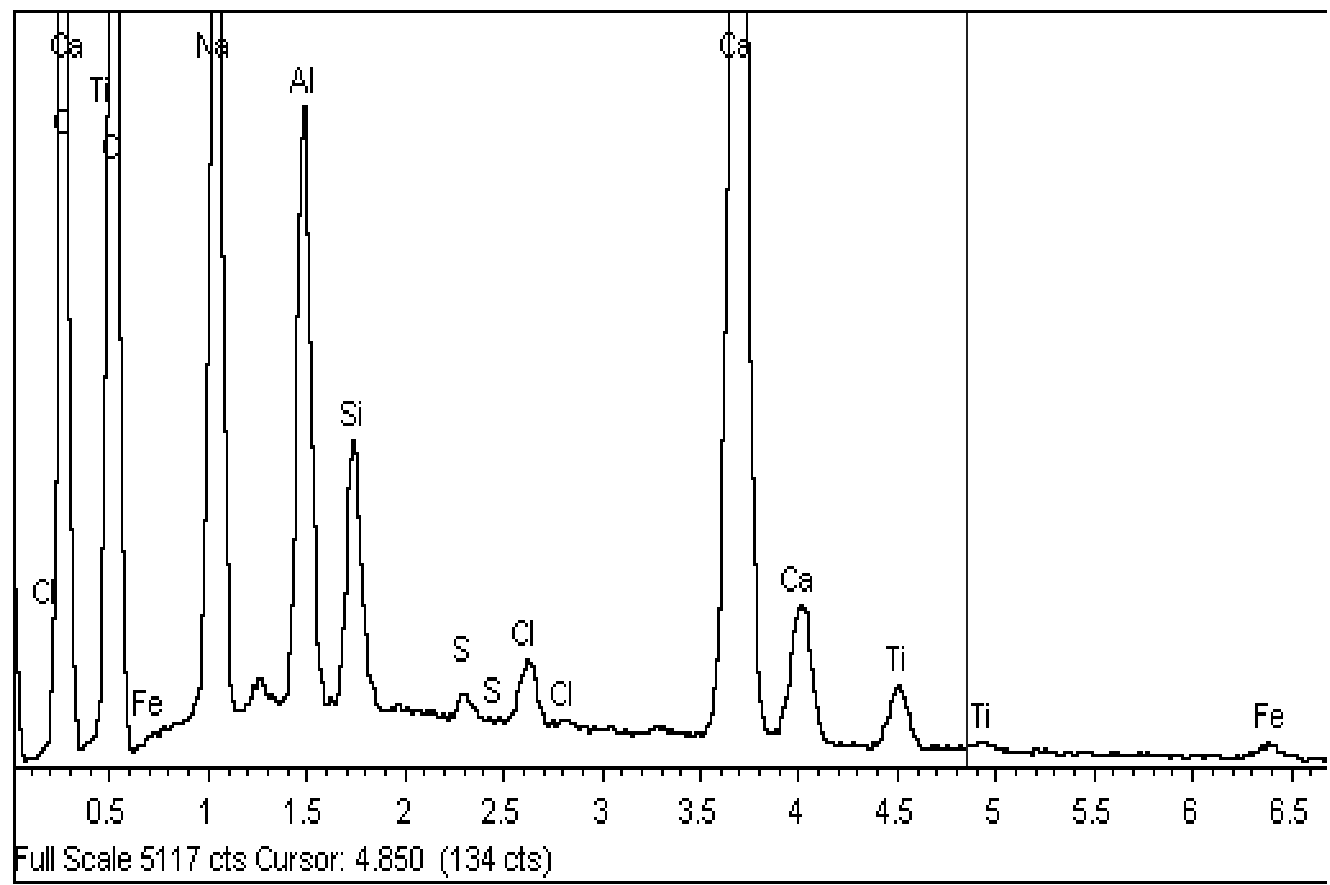

Figure $\mathbf{8}$ Their chemical composition is consistent, and evidences that they are derived from the original cancrinite phase in the RM.

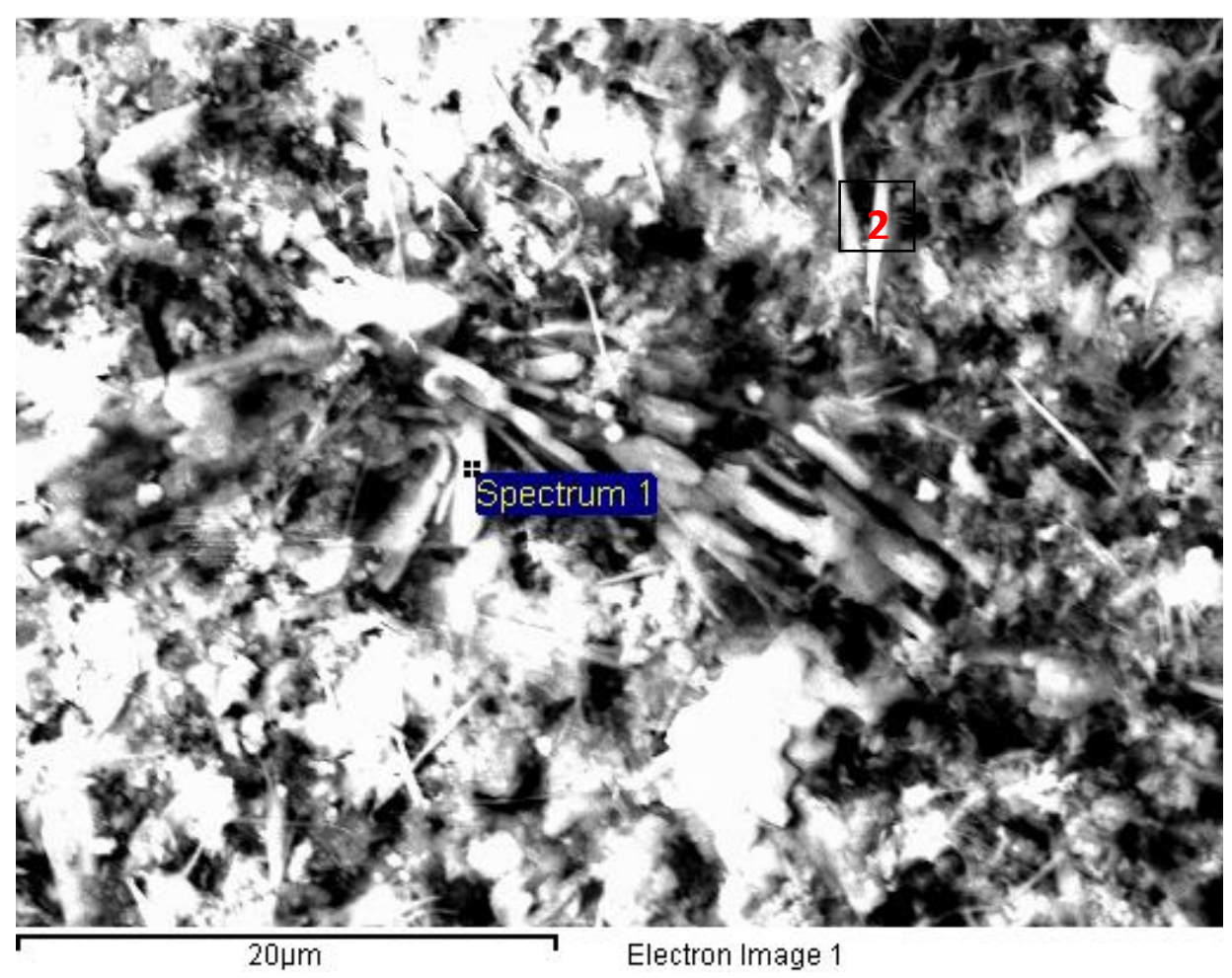

Figure 9 Hydrates formed in the RM /lime paste at 1 month, including fan-shaped sprays of cancrinite crystals and hexagonal plates. The elemental composition of these hydrates appears in Figure 10 and Figure 11. 


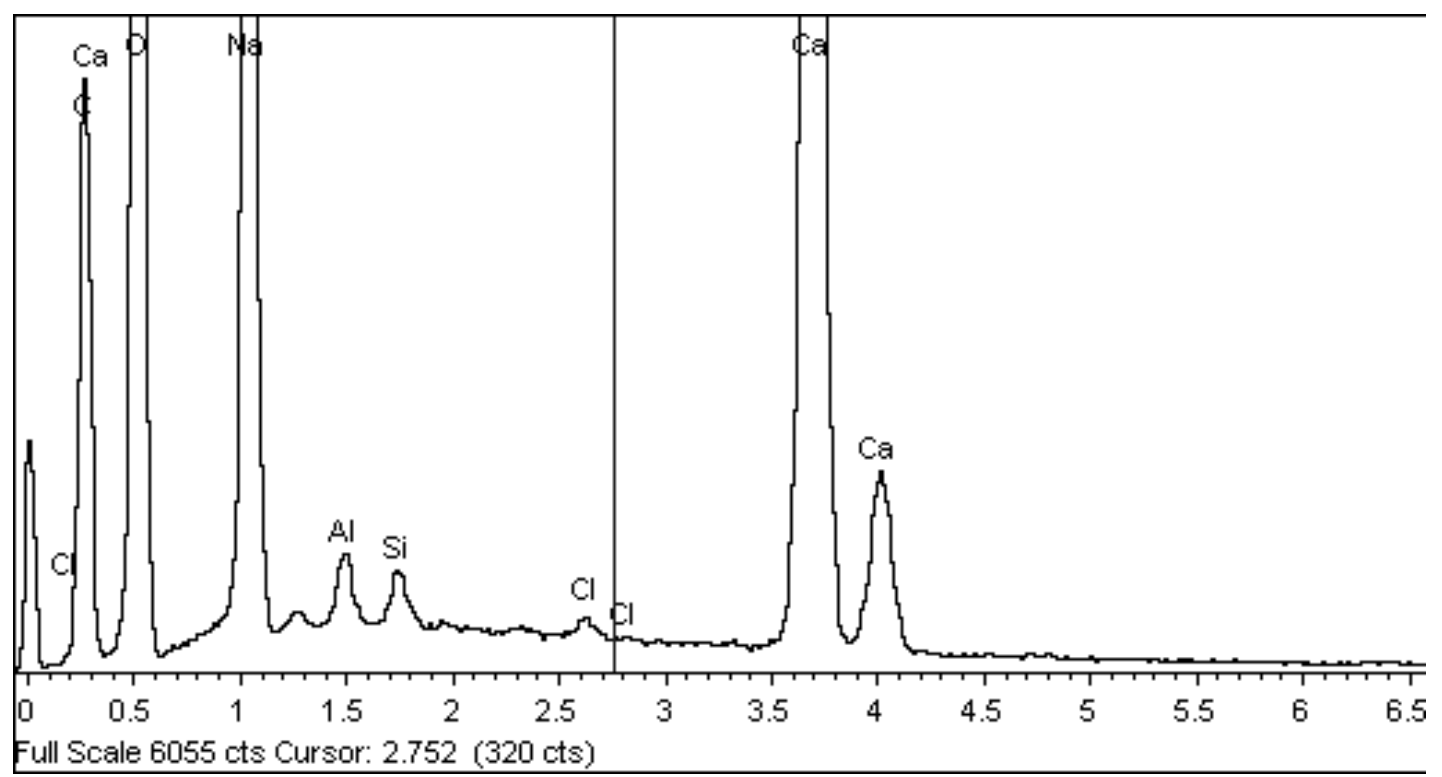

Figure 10 The main pozzolanic hydrates, marked as spectrum 1 in Figure 9, are fanshaped sprays of cancrinite crystals.

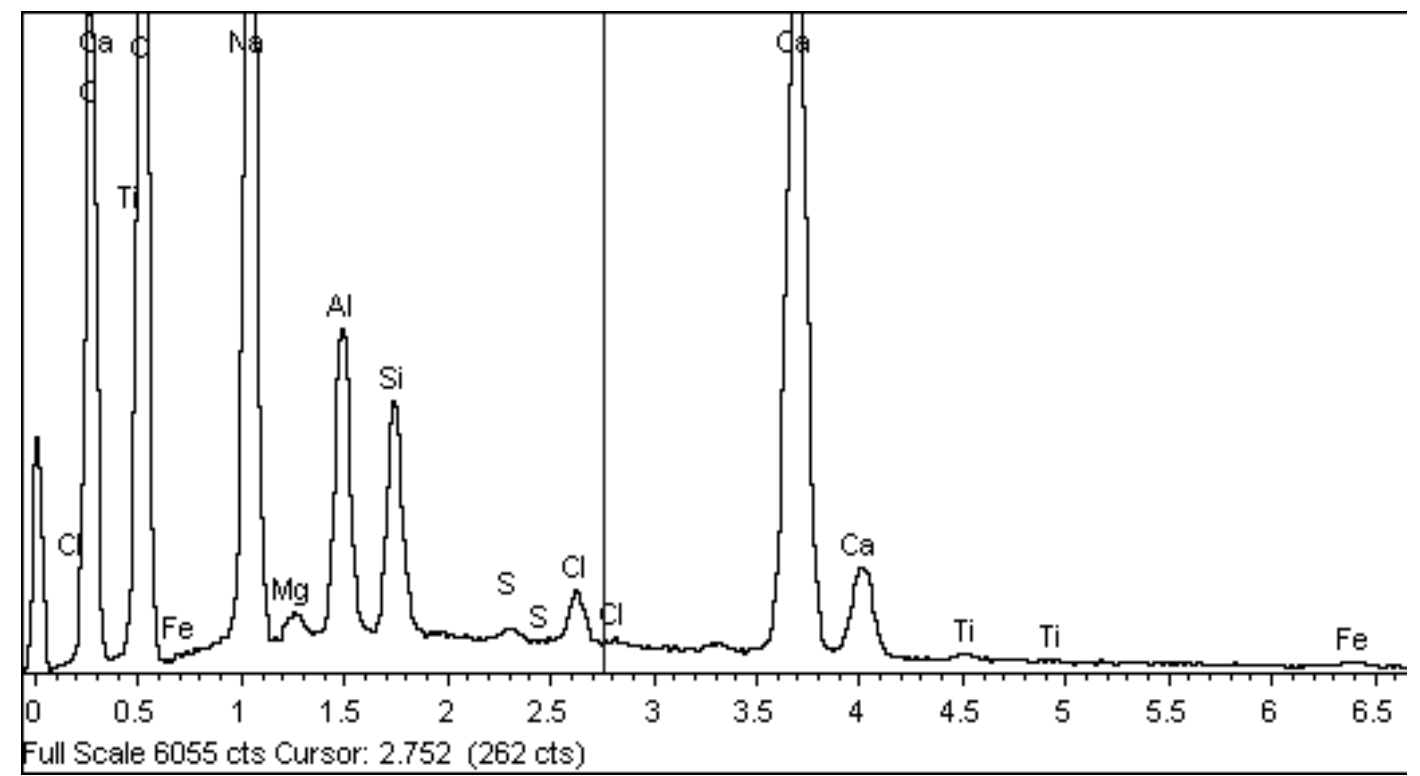

Figure 11 Hexagonal plates also appear. These are likely of the AFm type of hydrates $\left(\mathrm{C}_{4} \mathrm{AH}_{13} / \mathrm{C}_{2} \mathrm{AH}_{8}\right)$. However, their composition shows the presence of Na picked up by the scattered $\mathrm{X}$-Rays from the background and surroundings. 


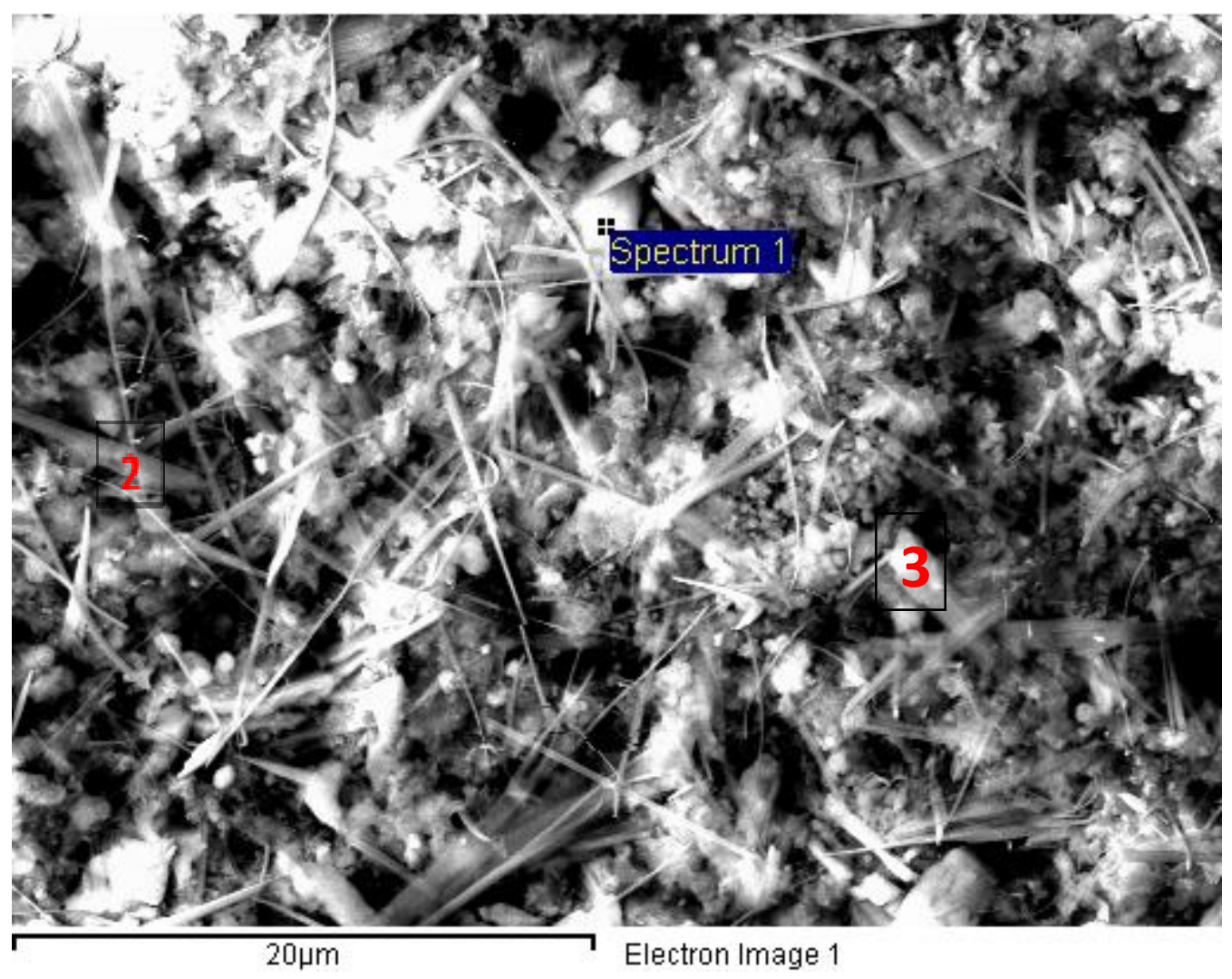

Figure 12 Detail of hydrates in the RM /lime pastes at 3 months. The elemental composition of the hydrates appears in Figures 13-14.

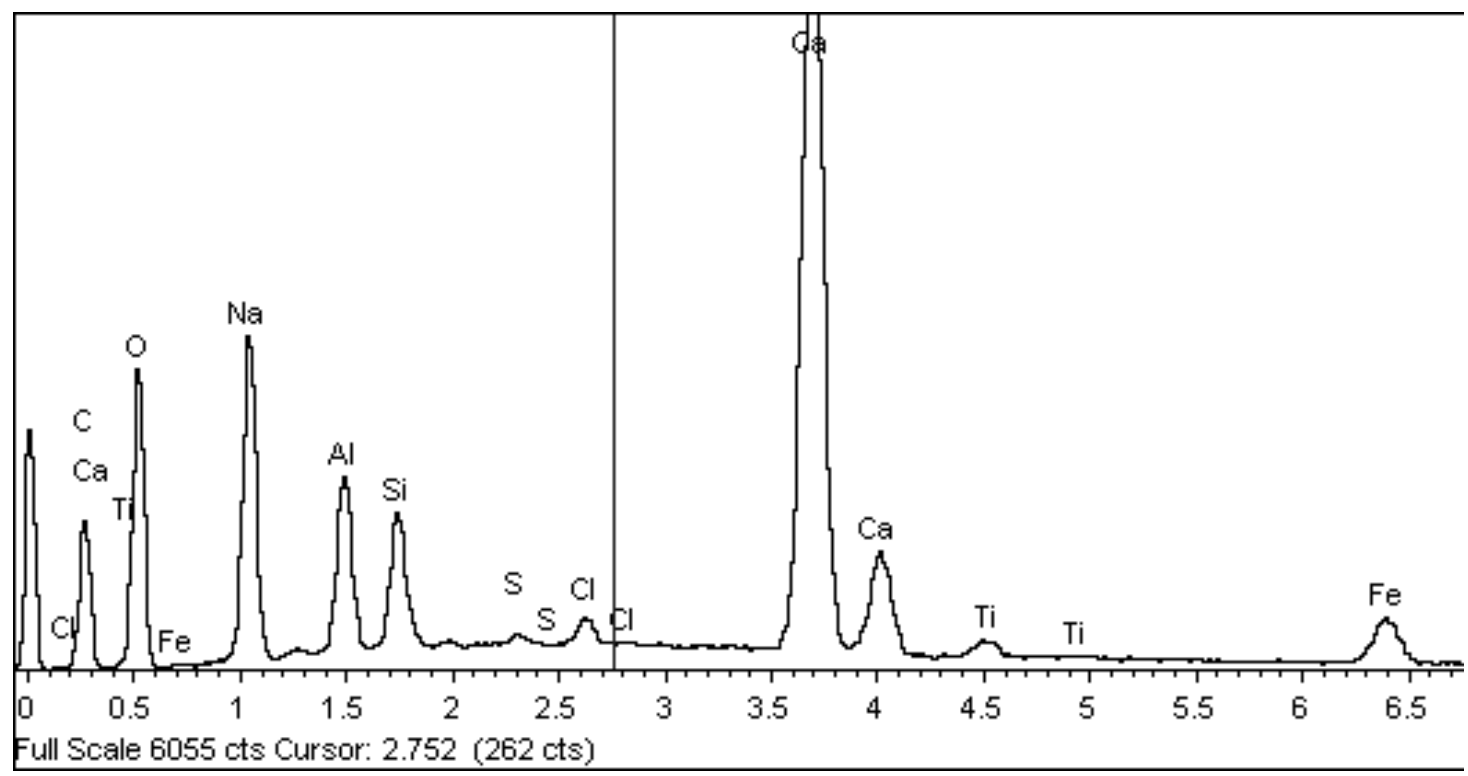

Figure 13 Elemental composition of the cubic hydrate phases (marked as spectrum 1 in Figure 12). These become more common over time, probably due to the transformation of the hexagonal hydrates. 


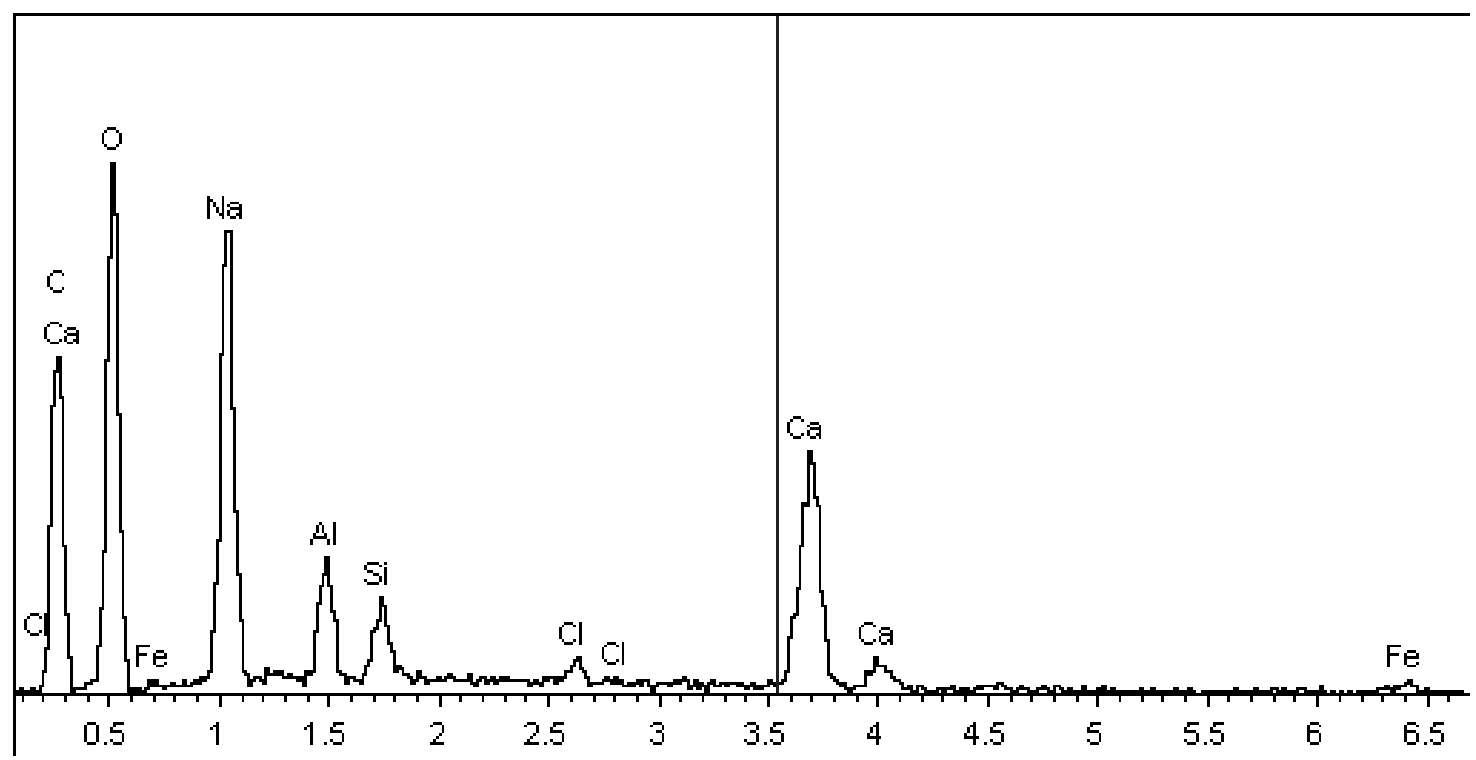

Figure 14 Elemental composition of the hydrates marked as 2-3 in Figure 12.

\subsection{Discussion: Pozzolanic Activity and Cementitious Properties}

As aforementioned, the pozzolanic properties of the RMs in the literature vary considerably. According to Sglavo et al. RM is substantially inert up to $900^{\circ} \mathrm{C}$, while Pera et al [12] found that RMs calcined at $600-800^{\circ} \mathrm{C}$ were pozzolanic but their activity was low, and Shi et al [14] obtained a RM of high pozzolanic activity, by heating a RM of high kaolinite content at $750^{\circ} \mathrm{C}$. Most authors attribute the pozzolanic activity of RMs to the transformation of the initial gibbsite into boehmite and transition aluminas (with reported pozzolanic behaviour) at $600-800^{\circ}$. However, as evidenced by the XRD and DSC results, gibbsite transforms much earlier in the Saudi RM $\left(280-300^{\circ} \mathrm{C}\right)$, agreeing with the greater activity for this RM found at a lower temperature.

The Saudi RM does not contain kaolinite. However, the Chapelle test and mechanical index results, and the comparison with other pozzolanic materials in the literature, indicate that the RM is moderately pozzolanic (Table 11). The SEM/EDXA and XRD analyses suggest that the main active phases are zeolites and feldespathoids. Therefore, the pozzolanic activity of the Saudi RM is mainly due to the presence and reaction of feldspathoids and zeolites, and the formation of zeolitic and feldspathoid-based hydrates. The SEM/EDXA evidenced that, at $300-400^{\circ} \mathrm{C}$, cancrinite is clearly active and produces pozzolanic hydrates in the form of needle-shaped and fan-shaped sprays of crystals. The XRD results showed that the maximum cancrinite content is found at $400^{\circ} \mathrm{C}$. Therefore, the pozzolanic activity of the RM is mainly due to the presence and reaction of feldspathoids.

Table 11 Summary of some of the principal physical properties and reactivity results.

SD-standard deviation.

\begin{tabular}{|c|c|c|c|c|c|c|c|c|}
\hline \multirow[b]{2}{*}{ RM } & \multirow{2}{*}{$\begin{array}{l}\text { SSA } \\
\left(\mathrm{m}^{2} / \mathrm{g}\right)\end{array}$} & \multirow{2}{*}{$\begin{array}{l}\text { Chapelle } \\
\text { test } \\
\mathrm{Ca}(\mathrm{OH})_{2} / \mathrm{g}\end{array}$} & \multirow[b]{2}{*}{$\mathrm{PH}$} & \multicolumn{2}{|c|}{ Setting times ( $\mathrm{min}$ ) } & \multirow{2}{*}{$\begin{array}{l}\text { Flexural } \\
\text { strength } \\
(\mathrm{MPa})\end{array}$} & \multirow{2}{*}{$\begin{array}{l}\text { Compr. } \\
\text { strength } \\
(\mathrm{MPa})\end{array}$} & \multirow{2}{*}{$\begin{array}{l}\text { Mechanical } \\
\text { index }\end{array}$} \\
\hline & & & & $\begin{array}{l}\text { Initial } \\
\text { set }\end{array}$ & Final set & & & \\
\hline $0^{\circ} \mathrm{C}$ & 9.03 & 251 & 10.64 & 170 & 180 & 0.73 & 2.02 & 6 \\
\hline $200^{\circ} \mathrm{C}$ & 8.87 & 277 & 10.23 & 150 & 130 & 0.62 & 1.96 & 6 \\
\hline
\end{tabular}




\begin{tabular}{llllllllll}
\hline $300^{\circ} \mathrm{C}$ & 9.91 & 406 & 10.34 & 240 & 260 & 0.86 & 2.50 & 8 \\
$400^{\circ} \mathrm{C}$ & 11.47 & 457 & 10.96 & 140 & 150 & 0.87 & 2.09 & 7 & \\
$750^{\circ} \mathrm{C}$ & 14.08 & 254 & 11.75 & 130 & 160 & 0.85 & 2.02 & 7 & \\
$1000^{\circ} \mathrm{C}$ & 2.75 & 280 & 10.28 & 110 & 140 & 0.88 & 2.18 & 7 \\
\hline
\end{tabular}

The results also indicate that the Saudi RM shows the greatest activity when sintered at $400^{\circ} \mathrm{C}$. The RMs sintered at 300 and $400^{\circ} \mathrm{C}$ combine the most lime in the Chapelle test, and they reached the greatest strengths and mechanical index (Table 11). In addition, the RM at $400^{\circ} \mathrm{C}$ sets the fastest, closely followed by the RM sintered at $750^{\circ} \mathrm{C}$ which reached a comparable mechanical index and the greatest SSAs. Hence, the optimum thermal treatment that enhances pozzolanic activity lies c. $400^{\circ} \mathrm{C}$ as evidenced by the highest lime combination and greatest mechanical indices.

At $\mathrm{c} .700^{\circ} \mathrm{C}$, the specific surface area of the RM particles is still high, and the RM combines significant lime and has a mechanical index comparable to the lower temperature. According to the XRD and DSC results, at $750^{\circ} \mathrm{C}$-boehmite, sodalite and calcite have disappeared but there is still significant cancrinite. This agrees with the main pozzolanic activity being driven by this mineral.

Negative effects of the thermal treatment were evidenced over $750^{\circ} \mathrm{C}$. These are the decrease in specific surface area (Table 11), due to the melting and agglomeration of cancrinite (DSC results in Figure 2), devitrification and crystallisation of nepheline, $C_{3} A$ and gehlenite $\left(1000^{\circ} \mathrm{C}\right)$ at the expense of cancrinite and chantalite which disappear (Table 6 and Figure 1).

\section{Conclusions}

The Saudi RM is pozzolanic and not cementitious because, in Ma'adem, the Bayer process temperature $\left(\mathrm{c} .270^{\circ} \mathrm{C}\right)$ is not high enough for hydraulic calcium silicates to form. Thermal treatments enhanced reactivity. The heated RMs make hydrated lime set between two and three times faster than alone, hence they are pozzolanic. The RM is moderately pozzolanic, and its activity is mainly due to the presence and reaction of feldespathoids and the formation of zeolitic and feldspathoid-based hydrates. Cancrinite is active, and it produces pozzolanic hydrates in the form of needle-shaped and fan-shaped sprays of crystals. AFm phases were also found however, the main pozzolanic hydrates seem to be of a zeolitic nature. Despite the occurrence of nepheline, $C_{3} A$ and traces of gehlenite at $1000^{\circ} \mathrm{C}$, the formation of pozzolanic hydrates that result in setting and strength development is greater at lower temperature $\left(300-400^{\circ} \mathrm{C}\right)$. The RM sintered at 300 and $400^{\circ} \mathrm{C}$ combines the most lime in the Chapelle test, and reached the greatest strengths and mechanical index. The $\left(400^{\circ} \mathrm{C}\right)$ sets the fastest closely followed by the RM sintered at $750^{\circ} \mathrm{C}$ which reached a comparable mechanical index.

The positive effects of the thermal treatment can be seen below $750^{\circ} \mathrm{C}$ (loss of water in the zeolite/feldespathoids, and destruction of the crystal structures of the clay minerals inherited form the parent bauxite). Negative effects are evidenced over $750^{\circ} \mathrm{C}$ including a decrease in specific surface area, devitrification and crystallisation. The optimum thermal treatment that enhances pozzolanic activity lies $c .400^{\circ} \mathrm{C}$ as evidenced by the highest lime combination and greatest mechanical indices.

The RM consists of gibbsite and boehmite, inherited from the bauxite, and cancrinite, chantalite and sodalite formed during the Bayer process. The $\mathrm{CaO}$, added during refining, has transformed the original goethite into hematite, and caused the occurrence of cancrinite. The Saudi RM has high $\mathrm{SiO}_{2}$ 
content and high alkalinity, the chloride and carbon contents are low, and no toxic elements were found. It presents abundant specific surface area available for reaction, superior to commercial CEM II and other pozzolanic and cementitious materials such as FA and GGBS.

\section{Acknowledgments}

The authors thank Abdul Malik Shaheen of Ma'adem for providing valuable information of the processing and refining process of the bauxite ore in the Ma'adem refineries. The authors also thank the Government of Saudi Arabia, Technical \& Vocational Training Corporation and the Saudi Arabian Cultural Bureau for their support and for financing the project. We thank our colleagues in the Civil Engineering laboratories in particular, M. Grimes, our Chief Technician D. McAuley and M. Gilligan for their assistance with testing. The authors thank Dr R. Goodhue of ICRAG / Geochemistry TCD, and Dr J. Canavan, Geography Department, TCD, Dr. A. Rafferty, of the Centre for Adaptive Nanostructures and Nanodevices, TCD and D. Daly of AMBER, the SFI Research Centre for Advanced Materials and BioEngineering Research and CRANN Institute, TCD, for their assistance with the analyses.

\section{Author Contributions}

O. Alelweet: undertaking the tests and analyses, studying background and results, presenting the results as part of his PhD. S. Pavia: PhD supervisor, SEM analyses, discussion and writing the paper. Z. Lei: Interpretation and presentation of XRD results.

\section{Competing Interests}

The authors have declared that no competing interests exist.

\section{References}

1. Khairul M, Zanganeh J, Moghtaderi B. The composition, recycling and utilisation of bayer red mud. Resour Conserv Recycl. 2019; 141: 483-498.

2. Evans K. The history, challenges, and new developments in the management and use of bauxite residue. J Sustain Metall. 2016; 2: 316-331.

3. Kumar S, Kumar R, Bandopadhyay A. Innovative methodologies for the utilisation of wastes from metallurgical and allied industries. Resour Conserv Recycl. 2006; 48: 301-314.

4. Mishra B, Gostu S. Materials sustainability for environment: Red-mud treatment. Front Chem Sci Eng. 2017; 11: 483-496.

5. Hind AR, Bhargava SK, Grocott SC. The surface chemistry of bayer process solids: A review. Colloids Surf A Physicochem Eng Asp. 1999; 146: 359-374.

6. Pontikes Y, Angelopoulos GN. Bauxite residue in cement and cementitious applications: Current status and a possible way forward. Resour Conserv Recycl. 2013; 73: 53-63.

7. Liu W, Yang J, Xiao B. Review on treatment and utilization of bauxite residues in China. Int J Miner Process. 2009; 93: 220-231.

8. Klauber C, Gräfe M, Power G. Bauxite residue issues: II options for residue utilization. Hydrometallurgy. 2011; 108: 11-32. 
9. Yang J, Xiao B. Development of unsintered construction materials from red mud wastes produced in the sintering alumina process. Constr Build Mater. 2008; 22: 2299-2307.

10. Liu X, Zhang N, Sun H, Zhang J, Li L. Structural investigation relating to the cementitious activity of bauxite residue-Red mud. Cem Concr Res. 2011; 41: 847-853.

11. Yalçın N, Sevinç V. Utilization of bauxite waste in ceramic glazes. Ceram Int. 2000; 26: 485-493.

12. Pera J, Boumaza R, Ambroise J. Development of a pozzolanic pigment from red mud. Cem Concr Res. 1997; 27: 1513-1522.

13. Manfroi EP, Cheriaf M, Rocha JC. Microstructure, mineralogy and environmental evaluation of cementitious composites produced with red mud waste. Constr Build Mater. 2014; 67: 29-36.

14. Shi C, Grattan-Bellew PE, Stegemann JA. Conversion of a waste mud into a pozzolanic material. Constr Build Mater. 1999; 13: 279-284.

15. Sglavo VM, Campostrini R, Maurina S, Carturan G, Monagheddu M, Budroni G, et al. Bauxite 'red mud' in the ceramic industry. Part 1: Thermal behaviour. J Eur Ceram Soc. 2000; 20: 235244.

16. Shaheen AM. The bauxite refining process of the Ma'adem industries in the Kingdom of Saudi Arabia. Pers Com Ma'adem. 2020.

17. Berenguer R, Lima N, Valdés A, Medeiros M, Lima N, Delgado J, et al. Durability of concrete structures with sugar cane bagasse ash. Adv Mater Sci Eng. 2020. doi: 10.1155/2020/6907834.

18. Filho JH, Gobbi A, Pereira E, Quarcioni VA, Medeiros MH. Atividade pozolânica de adições minerais para cimento portland (parte I): Índice de atividade pozolânica (IAP) com cal, difração de raios-X (DRX), termogravimetria (TG/DTG) e chapelle modificado. Matéria (Rio J). 2017; 22. doi: 10.1590/S1517-707620170003.0206.

19. ABNT. NBR 15895 - Materiais pozolânicos - Determinação do teor de hidróxido de cálcio fixado - Método chapelle modificado [Internet]. São Paulo: Associação Brasileira de Normas Técnicas; 2010. Available from: https://www.abntcatalogo.com.br/norma.aspx?ID=80644.

20. Srikanth S, Ray AK, Bandopadhyay A, Ravikumar B, Jha A. Phase constitution during sintering of red mud and red mud - Fly ash mixtures. J Am Ceram Soc. 2005; 88: 2396-2401.

21. Mukiza E, Zhang LL, Liu X, Zhang N. Utilization of red mud in road base and subgrade materials: A review. Resour Conserv Recycl. 2019; 141: 187-199.

22. Singh $S$, Aswath M, Ranganath R. Effect of mechanical activation of red mud on the strength of geopolymer binder. Constr Build Mater. 2018; 177: 91-101.

23. Toniolo N. Novel geopolymers incorporating silicate waste. Erlangen: Friedrich-alexanderuniversität erlangen-nürnberg (FAU); 2019.

24. Hairi SN, Jameson GN, Rogers JJ, MacKenzie KJ. Synthesis and properties of inorganic polymers (geopolymers) derived from bayer process residue (red mud) and bauxite. J Mater Sci Technol. 2015; 50: 7713-7724.

25. Gong C, Yang N. Effect of phosphate on the hydration of alkali-activated red mud-slag cementitious material. Cem Concr Res. 2000; 30: 1013-1016.

26. Choo H, Lim S, Lee W, Lee C. Compressive strength of one-part alkali activated fly ash using red mud as alkali supplier. Constr Build Mater. 2016; 125: 21-28.

27. Ye J, Zhang $W$, Shi D. Properties of an aged geopolymer synthesized from calcined ore-dressing tailing of bauxite and slag. Cem Concr Res. 2017; 100: 23-31.

28. Breck DW. Zeolite molecular sieves: Structure, chemistry, and use. New Jersey: John Wiley \& Sons; 1974. 
29. Zhao H, Deng Y, Harsh JB, Flury M, Boyle JS. Alteration of kaolinite to cancrinite and sodalite by simulated hanford tank waste and its impact on cesium retention. Clays Clay Miner. 2004; 52: 1-13.

30. Castaldi P, Silvetti M, Santona L, Enzo S, Melis P. XRD, FTIR, and thermal analysis of bauxite oreprocessing waste (red mud) exchanged with heavy metals. Clays Clay Miner. 2008; 56; 4: 461469.

31. Atasoy A. An investigation on characterization and thermal analysis of the aughinish red mud. J Therm Anal Calorim. 2005; 81: 357-361.

32. Paglia G, Buckley CE, Rohl AL. Boehmite derived $\gamma$-alumina system. 1. Structural evolution with temperature, with the identification and structural determination of a new transition phase, $\gamma$ alumina. Chem Mater. 2004; 16: 220-236

33. Malki A, Mekhalif Z, Detriche S, Fonder G, Boumaza A, Djelloul A. Calcination products of gibbsite studied by X-ray diffraction, XPS and solid-state NMR. J Solid State Chem. 2014; 215: 815.

34. Rivas MJ, Cabral A, Paiva A, Angélica R, Neves R, Scheller T. Thermal behavior and evolution of the mineral phases of Brazilian red mud. J Therm Anal Calorim. 2011; 104: 635-643.

35. Castaldi P, Silvetti M, Enzo S, Deiana S. X-Ray diffraction and thermal analysis of bauxite oreprocessing waste (red mud) exchanged with arsenate and phosphate. Clays Clay Miner. 2011; 59; 2: 189-199.

36. ASTM International. ASTM C618 - 19 standard specification for coal fly ash and raw or calcined natural pozzolan for use in concrete. West Conshohocken: ASTM International; 2019.

37. Alelweet $\mathrm{O}$, Pavia S. An evaluation of the feasibility of several industrial wastes and natural materials as precursors for the production of alkali activated materials. Int J Archit Civ Constr Sci. 2019; 13: 745-752.

38. Alelweet $\mathrm{O}$, Pavia S. Potential of a low-calcium fly ash (FA) for the production of alkali-activated materials. Proceedings of the Civil Engineering Research in Ireland 2020; 2020 August 28; Cork Ireland. Cork: Cork institute of technology.

39. Alelweet O, Pavia S. Fitness of a high-calcium slag for the production of alkali activated materials. Proceedings of the 1st International Conference on Construction, Energy, Environment and Sustainability - CEES 2021; 2021 October 12-15; Coimbra Portugal. Coimbra Portugal: Itecons.

40. Walker R, Pavia S. Behaviour and properties of lime-pozzolan pastes. Proceedings of the 8th International Masonry Conference Dresden; 2010 July 4-7; Dresden. Dresden: Technische Universität Dresden.

41. Walker R, Pavia S. Physical properties and reactivity of pozzolans, and their influence on the properties of lime-pozzolan pastes. Mater Struct. 2011; 44: 1139-1150.

42. Massaza F. Lea's chemistry of cement and concrete 4th edition. London: Arnold; 1998. 


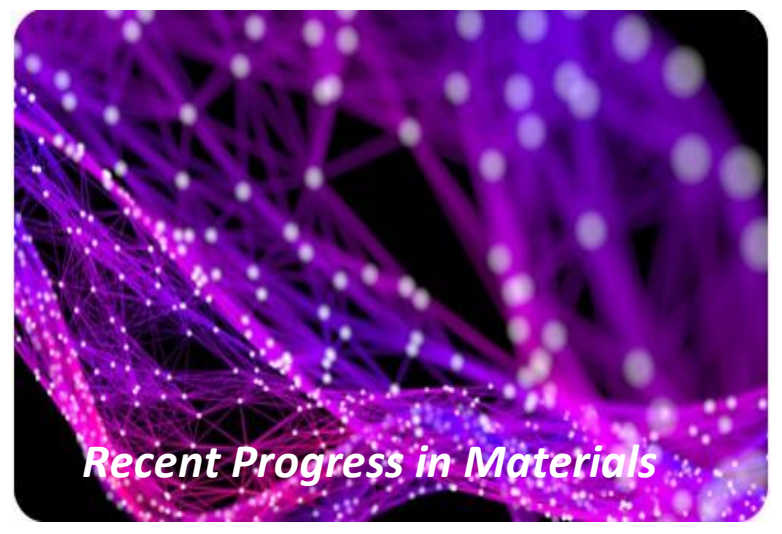

Enjoy Recent Progress in Materials by:

1. Submitting a manuscript

2. Joining in volunteer reviewer bank

3. Joining Editorial Board

4. Guest editing a special issue

For more details, please visit:

http://www.lidsen.com/journals/rpm 